РАССТРОЙСТВА СОЗНАНИЯ ПОСЛЕ ПЛАНОВЫХ ОПЕРАЦИЙ У БОЛЬНЫХ С ЦЕРЕБРО-ВАСКУЛЯРНОЙ НЕДОСТАТОЧНОСТЬЮ

\author{
В. В. Лихванцев ${ }^{1,2}$, Ю. В. Ильин ${ }^{3}$, Е. А. Шмелева ${ }^{1,2}$, \\ М. П. Данилов ${ }^{2}$ Ю. В. Скрипкин ${ }^{2}$, О. А. Гребенчиков ${ }^{1,2}$ \\ ${ }^{1}$ НИИ общей реаниматологии им. В. А. Неговского, Москва, Россия \\ 107031, Москва, ул. Петровка, д. 25, стр. 2 \\ ${ }^{2}$ Московский областной научно-исследовательский клинический институт \\ им. М. Ф. Владимирского, Москва, Россия \\ 129110, г. Москва, ул. Щепкина, д. 61/2 \\ ${ }^{3}$ Главный клинический военный госпиталь ФСБРФ, Голицыно, Россия \\ Московская область, г. Голицыно, Петровское шоссе, д. 48
}

\title{
Consciousness Disorders after Elective Surgery in Patients with Cerebrovascular Insufficiency
}

\author{
V. V. Likhvantsev ${ }^{1,2}$, Yu. V. Ilyin ${ }^{3}$, E. A. Shmeleva, ${ }^{1,2}$ M. P. Danilov ${ }^{2}$, Yu. V. Skripkin ${ }^{2}$ O. A. Grebenchikov ${ }^{1,2}$ \\ ${ }^{1}$ V. A. Negovsky Research Institute of General Reanimatology, Moscow, Russia \\ 25, Petrovka St., Build. 2, Moscow 107031 \\ ${ }^{2}$ M. F. Vladimirsky Moscow Regional Research Clinical Institute, Moscow, Russia \\ 61/2, Shchepkin St., Moscow 129110, Russia \\ Main Clinical Military Hospital, Federal Security Service of the Russian Federation \\ 48, Petrovskoe Shosse, Golitsyno, Moscow Region
}

\begin{abstract}
Цель исследования - изучить влияние церебральной «гипоксемии» на показатели нейроповреждения, основываясь на диагностике послеоперационных когнитивных нарушений и показателей маркера нейро-повреждения белка S100b, изучить взаимосвязь различных послеоперационных когнитивных расстройств. Материал и методы. Исследование проведено у 48 больных не кардиохирургического и не нейрохирургического профиля с подтвержденным церебро-васкулярным заболеванием, оперированных в условиях тотальной внутривенной анестезии на основе пропофола и тотальной миоплегии. Уровень белка S100b в крови определяли после события церебральной «гипоксемии», выявляемой транкраниальной оксиметрией. Послеоперационный делирий диагностировали методом ICU-CAM; послеоперационную когнитивную дисфункцию - на основании Монреальской шкалы когнитивной дисфункции в сроки: 7 дней, 1 месяц, 3 месяца, 6 месяцев, 1 год, - используя контрольную группу, выполнена стандартизация этих показателей в Z-оценки. Результаты. Церебральная десатурация привела к развитию ранних послеоперационных расстройств: и делирия, и дисфункции, - в 72,7 \% случаев. Показатели церебральной сатурации умеренно, но достоверно коррелировали с нейропсихологическими показателями на 30 сутки исследования и в 3 месяца послеоперационного периода, а также, но уже сильнее, с уровнем белка S100b. Вероятность послеоперационных когнитивных

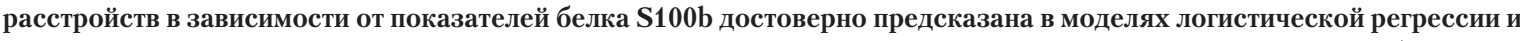
ROC-анализа. Частота ранней и стойкой когнитивной дисфункции статистически значимо различалась у больных с предшествующим делирием, в модели логистической регрессии, достоверно предсказана связь этого события и выраженности нейропсихологических показателей на 7 сутки послеоперационного периода. Заключение. У больных с церебро-васкулярными заболеваниями эпизоды церебральной гипоксемии опасны. При их возникновении повышается вероятность развития послеоперационных когнитивных расстройств, в том числе длительных. Ранним предиктором послеоперационных когнитивных расстройств является уровень белка S100b выше порогового значения в 0,26 нг/мл. Ключевые слова: церебро-васкулярные заболевания, не кардиохирургические операции, послеоперационный делирий, послеоперационная когнитивная дисфункция, церебральная оксиметрия, белок S100b.
\end{abstract}

Objective: to study the impact of cerebral hypoxemia on the indicators of neuroinjury, by relying on the diagnosis of postoperative cognitive impairments, and the neuroinjury marker S100b protein and to examine the relationship of postoperative cognitive mpairments. Subjects and methods. Forty-eight non-cardiac surgical and non-neurosurgical patients with verified cerebrovascular disease, who had been operated on under total intravenous anesthesia with propofol and total myoplegia, were examined. Blood S100b protein levels were determined after cerebral hypoxemia detectable by transcra-

\footnotetext{
Адрес для корреспонденции:

Ильин Юрий Владимирович

E-mail: milocks@rambler.ru
}

Correspondence to:

Ilyin Yuri Vladimirovich

E-mail: milocks@rambler.ru 


\section{Problems of anesthesia}

nial oximetry. Postoperative delirium was diagnosed by the ICU-CAM test; postoperative cognitive dysfunction was diagnosed according to the Montreal cognitive assessment scale in the periods: 7 days, 1, 3, and 6 months, and 1 year, by using the control group, the $\mathbf{Z}$ scores of these indicators were standardized. Results. Cerebral desaturation led to early postoperative disorders, such as delirium and dysfunctions, in $72.7 \%$ of the cases. Cerebral saturation parameters correlated moderately, but significantly with neuropsychological indicators at 30 days of the study and 3 months after surgery and just stronger with S100b protein level. The risk of postoperative cognitive impairments in relation to the values of S100b protein was validly predicted in the models of logistic regression and ROC analysis. The rate of early and persistent cognitive dysfunction differed statistically significantly in patients with prior delirium; the logistic regression model validly predicted a relationship between this event and the neuropsychological indicators on 7 days postsurgery. Conclusion. In the patients with cerebrovascular diseases, cerebral hypoxemic episodes are dangerous. When they occur, there is an increased risk of postoperative cognitive impairments, including long-term problems. The above-threshold S100b protein concentration of $0.26 \mathrm{ng} / \mathrm{mg}$ is an early predictor of postoperative cognitive disorders. Key words: cerebrovascular diseases, non-cardiac surgery, postoperative delirium, postoperative cognitive dysfunction, cerebral oximetry, S100b protein.

DOI:10.15360/1813-9779-2015-1-39-52

\section{Введение}

Если еще совсем недавно основное внимание исследователей, занимающихся проблемой послеоперационных изменений центральной нервной системы(ЦНС), было сфокусировано на неблагоприятных неврологических событиях, не заметить которые было невозможно (инсульты, судорожный синдром, опистотонус и т. д.) [1], то, в настоящее время, все больший интерес вызывают менее выраженные нарушения, проявляющиеся, в первую очередь, изменениями высших психических (когнитивных) функций [2, 3]. Хотя, прогноз подобных состояний считается, в целом, благоприятным (у большинства больных когнитивные расстройства регрессируют в течение 6 месяцев после операции), имеются отдельные свидетельства взаимосвязи послеоперационных когнитивных нарушений с ухудшением качества жизни, и, даже, увеличением летальности [4-6]. Последнее обстоятельство обуславливает возрастающий интерес анестезиологов к обсуждаемой проблеме.

Послеоперационные расстройства сознания принято разделять на послеоперационный делирий (ПОД) и послеоперационную когнитивную дисфункцию (ПОКД).

Делирий определяется Международной Классификацией Болезней (МКБ-10) как этиологический неспецифический органический церебральный синдром, характеризующийся нарушениями сознания, внимания, восприятия, мышления, памяти, психомоторного поведения, эмоций, нарушением чередования снабодрствования [7]. Развивается у 10-70\% пациентов старше 65 лет в 1-4 сутки послеоперационного периода $[8,9]$. Общепринятая модель развития делирия предполагает наличие предрасполагающих и инициирующих факторов: пожилой возраст, образовательный ценз и наличие серьезных сопутствующих заболеваний повышают риск возникновения ПОД [8, 10, 11]; среди пусковых факторов едва ли не главным признается церебральная гипоксемия [12].

Послеоперационная когнитивная дисфункция не значится в перечне заболеваний и состояний Международной Классификации Болезней (МКБ) [13] и DSM-IV $[14,15]$. Следует отметить, что термин «умеренные ког-

\section{Introduction}

In most previous studies much attention of researchers dealing with problems of postoperative changes of the central nervous system (CNS) was focused on easy-to-notice unfavorable neurological events like strokes, convulsive disorder, opisthotonos, etc. [1]. Most recently the focus of interest was skewed to less evident disorders manifesting themselves primarily as changes of higher psychic (cognitive) functions [2, 3]. Although the forecast of these conditions is considered, on the whole, to be favorable (in most patients, cognitive disorders regress within 6 post-operative months), there is some evidence of interconnection of postoperative cognitive disturbances with impaired life quality and even increased mortality [4-6]. The latter circumstance ensures the increasing interest of anesthetists to the problem in question.

Postoperative disturbances of consciousness are subdivided into postoperative delirium (POD) and postoperative cognitive dysfunction (POCD). Delirium is defined by the International Classification of Diseases (ICD-10) as an etiologically non-specific, organic cerebral syndrome characterized by troubles of consciousness, attention, perception, thinking, memory, psychomotor behavior, emotions, and wake-sleep cycle [7]. It develops in 10-70\% patients over 65 years old on the 1st - 4th day of the postoperative period $[8,9]$. The generally accepted delirium model assumes the presence of predisposing and initiating factors: elderly age, education qualification and presence of serious coexisting illnesses increase the POD risk [8, 10, 11]; cerebral hypoxemia is considered to be the main among the starting factors [12].

Postoperative cognitive dysfunction is not listed among the diseases and states in the International Classification of Diseases (ICD) [13] and DSM-IV [14, 15]. It is to be noted that the term «mild cognitive impartment» was included in the tenth revision of the International Classification of Diseases as an independent diagnostic position [16], but this revision does not mention the cause-effect relation with the surgery. According to modern vision, POCD is a reduction in various neuropsychological areas including memory, attention concentration, and educability [17]. Unlike the typical patient with POD, POCD is marked by absence of disorientation, 
нитивные расстройства» (англ.: mildcognitiveimpartment) был включен в Десятый пересмотр Международной Классификации Болезней, как самостоятельная диагностическая позиция [16], но указания на причинно-следственную связь с хирургическим вмешательством в этом пересмотре отсутствуют. По современным представлениям ПОКД представляет собой снижение в различных нейропсихологических областях, включая память, концентрацию внимания, способность к обучению [17]. В отличии от типичного пациента с ПОД при ПОКД отсутствуют дезориентация, обманы восприятия, цикличность симптоматики; но наблюдаются значительные отличия от исходного уровня в когнитивных областях [18-21]. Распространенность ПОКД при не- кардиохирургических вмешательствах в европейских странах была изучена в крупнейшем эпидемиологическом исследовании International Studyof Postoperative Cognitive Dysfunction (ISPOCD), проведенном в 1998 г. В результате исследования было обнаружено, что когнитивная дисфункция присутствовала у $26 \%$ пожилых пациентов через 1 неделю и у 10\% через 3 месяца после операции [22]. ПОКД можно разделить на острую, промежуточную и позднюю или долгосрочную дисфункцию [22]. Термин «острая ПОКД» используется для описания когнитивных нарушений, обнаруженных на 6-7-й день после операции, «промежуточная ПОКД» - для изменений, сохраняющихся в течение 3 месяцев, и «долгосрочная ПОКД» - для изменений, которые могут длиться до 1-2 лет и, даже, сохраняться пожизненно [3, 6, 10, 23-28].

Для оценки ПОДв настоящее время рекомендован только метод ICU-CAM [29-33], тогда как для диагностики ПОКД необходимо использовать набор тестов, состоящий не менее чем из 4-5 шкал бальной оценки. Последнее время для оценки «не дементных» когнитивных расстройств в ряду нейро-психических тестов все большую популярность приобретает Монреальская шкала когнитивной оценки (MoCA-test), применение которой обосновано отличными показателями чувствительности, специфичности и превосходством над аналогичными диагностическими тестами [34-38].

Учитывая схожесть, если не сказать идентичность, предполагаемых механизмов развития ПОД и ПОКД, есть основания полагать, что ПОД является, если не причиной, то одним из наиболее распространенных предикторов последующих ПОКд.

С целью проверки данного предположения и было предпринято настоящее исследование. Причем, выполнено оно было у больных с церебро-васкулярной недостаточностью, т.е. пациентов, наиболее чувствительных к периоперационной гипоксемии.

\section{Материал и методы}

Общая характеристика больных и методы исследования. Исследование проведено у 48 больных с сопутствующим церебро-васкулярным заболеванием, оперированных в филиале «Мединцентр» ГлавУпДК при МИД РФ и ГКВГ ФСБ РФ в 2011-2013 гг. Все больные письменно подтвердили согласие на участие в исследовании. false perception, or symptomatology cycles; but there are significant differences from the initial level in the cognitive areas [18-21]. The POCD prevalence at non-cardiosurgical operations in European countries was covered in a major epidemiological study, International Study of Postoperative Cognitive Dysfunction (ISPOCD) carried out in 1998. The study discovered that cognitive dysfunction was present in $26 \%$ of aged patients after 1 week and in $10 \%$ after 3 postoperative months [22]. POCD can be subdivided into acute, intermediate and late or long-term dysfunction [22]. The term «acute POCD» is used for describing cognitive disturbances detected on the 6th $7^{\text {th }}$ day after the operation; «intermediate POCD» is used for changes persisting for 3 months; and «long-term POCD» is used for changes that may last for up to $1-2$ years or even for life [3, 6,10, 23-28].

Only the ICU-CAM method is now recommended for evaluating POD [29-33], whereas for diagnosing POCD, it is necessary to use a set of tests consisting of at least 4-5 point scales. Recently, to evaluate non-dement cognitive disturbances, the Montreal Cognitive Assessment (MoCA-test) has been becoming increasingly popular among the neuro-psychic tests. Its use is accounted for by excellent indicators of sensitivity, specificity and its superiority over similar diagnostic tests [34-38].

Considering the similarity or even identity of the supposed mechanisms of development of POD and POCD, there is every reason to believe that POD is a reason or at least one of the most wide-spread predictors of subsequent POCDs.

This study has been undertaken to verify this assumption in patients with cerebrovascular insufficiency, i.e., in patients who are most sensitive to perioperative hypoxemia.

\section{Materials and Methods}

General Characteristic of Patients and Study Methods.

The study included 48 patients with coexistent cerebrovascular disease who were operated on at the branch MedIntCentre of the Main Production and Commercial Direction for Servicing the Diplomatic Board at the Ministry of Foreign Affairs of the Russian Federation and at the Main Clinical Military Hospital of Federal Security Service of the Russian Federation in 2011 -2013. All patients gave their written consent to the participation in the study. The study was approved by local Ethics Committees prior to initiation.

\section{Inclusion criteria:}

1. Age over 65;

2. A cerebrovascular disease confirmed by an expertize;

3. Reduction of cognitive functions. Evaluation according to the MoCA-test scale - from 18 to 25 points.

\section{Exclusion criteria:}

1. Dementia;

2. Evaluation according to the MoCA-test scale - less than 18 points;

3. Old stroke or infarction of less than 6 months before this surgery;

4. Oncological disease or another grave chronic disease at the decompensation stage;

5. Movement restriction due to previous diseases;

6. The patient needs prolonged ALV;

7. The patient needs postoperative sedation; 
Таблица 1. Дозы препаратов, использованных для вводного наркоза/поддержания анестезии. Table 1. Doses of drugs used for anesthetic induction/anesthesia maintenance.

\begin{tabular}{|c|c|c|}
\hline \multirow[t]{2}{*}{ Drugs } & \multicolumn{2}{|c|}{ The doses of drugs on the stages of anesthesia } \\
\hline & induction & maintenance \\
\hline Propofol & $2.2+0.9 \mathrm{mg}^{*} \mathrm{~kg}^{-1}$ & $3.7+1.1 \mathrm{mg}^{*} \mathrm{~kg}^{-1 *}$ hour $^{-1}$ \\
\hline Phentanylum & $4 \mathrm{mg} * \mathrm{~kg}$ & $2.4+1.0 \mathrm{mg}^{*} \mathrm{~kg}^{-1 *}$ hour $^{-1}$ \\
\hline Nimbex & $0.05 \mathrm{mg}^{*} \mathrm{~kg}^{-1 *}$ hour $^{-1}$ & $0.05 \mathrm{mg}^{*} \mathrm{~kg}^{-1 *}$ hour $^{-1}$ \\
\hline
\end{tabular}

Note (примечание): drugs - препараты; the doses of drugs on the stages of anesthesia - дозы препаратов на этапах анестезии; induction - индукция; maintenance - поддержание; Propofol - пропофол; Phentanylum - фентанил; Nimbex - цисатракуриябезилат; $\mathrm{mg} * \mathrm{~kg}^{-1 *}$ hour $^{-1}-\mathrm{MГ}^{*} \mathrm{K \Gamma}^{-1 *} \mathrm{чac}^{-1}$.

\section{Критерии включения:}

1. Возраст старше 65 лет.

2. Подтвержденное заключением специалиста церебро-васкулярное заболевание.

3. Снижение когнитивных функций. Оценка по шкале MoCA-test от 18 до 25 баллов.

\section{Критерии исключения:}

1. Деменция.

2. Оценка по шкале MoCA-test менее 18 баллов.

3. Перенесенный инсульт или инфаркт давностью менее 6 месяцев до дня настоящей операции.

4. Наличие онкологического заболевания или другого тяжелого хронического заболевания в стадии декомпенсации.

5. Ограничения движений вследствие перенесенных заболеваний.

6. Больной (ая) нуждается в проведении продленной ИВЛ.

7. Больной (ая) нуждается в седации после операции

8. Хирургические осложнения в раннем послеоперационном периоде.

9. Другое оперативное вмешательство или медицинская манипуляция с анестезиологическим пособием в период исследования.

Метод анестезии. Интраоперационная защита всех больных проводилась методом тотальной внутривенной анестезии (TBA). Вводный наркоз состоял из последовательного введения пропофола и фентанила (табл. 1). Интубацию трахеи выполняли на фоне тотальной миоплегии под контролем TOF (TOF-Watch, Organon, Нидерланды) и мониторинга BIS (целевой уровень 45-55 ед.). Поддержание анестезии осуществляли теми же препаратами.

Всем пациентам проводили ИВЛ в режиме CMV аппаратом FabiusGS+ с интегрированным монитором InfinityM (Drägger, Германия).

В послеоперационном периоде больные получали инфузионную и симптоматическую терапию в соответствие с требованиями лечения основного и сопутствующих заболеваний по единому лечебному стандарту. Обезболивание: в первые сутки послеоперационного периода - морфин в дозе 10-20 мг/сутки, вторые - третьи сутки - морфин (0-15 мг/сутки) в комбинации с нестероидными противовоспалительными препаратами.

Мониторинг

1. ЭКГ с подсчетом ЧСС

2. АД неинвазивным методом.

3. $\mathrm{SpO}_{2}$ с пульсоксиметрической кривой.

4. Объема вдоха/выдоха.

5. $\mathrm{FiO}_{2}$;

6. $\mathrm{EtCO}_{2}$;

7. Частоты дыхания (ЧД)

8. Герметичности дыхательного контура.

9. BIS-мониторингприбором Aspect - 2000 или Vista, Aspect med. inc. (США).

Транкраниальную оксиметрию проводили прибором Fore-Sight (Casmed, USA). «Эпизодом церебральной «гипоксемии» (событием) считали снижение $\mathrm{SrO}_{2}$ на 3 мин и более до уровня на $20 \%$ ниже, наблюдаемого после индукции анестезии, до начала операции в условиях стабильной гемодинамики и $\mathrm{SpO}_{2}$ 98-100\%. При снижении $\mathrm{SrO}_{2}$ действовали в соответствие со следующим алгоритмом:
8. Surgical implications in the early postoperative period;

9. Another surgical intervention or medical manipulation with anesthetic aid during the study period.

Method of anesthesia.

The intraoperative protection of all patients was performed by method of total intravenous anesthesia (TIA). The anesthetic induction composed of consecutive injection of profopol and phentanylum (Table 1). The intubation of trachea was performed on the background of total myoplegia under TOF control (TOFWatch, Organon, Netherlands) and BIS monitoring (target level $45-55 \mathrm{U})$. The anesthesia was maintained with the same preparations.

All patients were subject to ALV in the CMV mode with a Fabius GS+ apparatus with integrated Infinity $\mathrm{M}$ monitor (Drägger, Germany).

During the postoperative period, the patients received infusion and symptomatic treatment in conformity with the requirements for treatment of the main and coexisting illnesses according to the single medical standard. Pain relief: on the first day of the postoperative period: morphine 10-20 mg/day, second and third day: morphine $(0-15 \mathrm{mg} /$ day $)$ combined with nonsteroid antiinflammatory preparations.

\section{Monitoring}

1. ECG with HR count;

2. ABP by non-invasive method;

3. Spot $_{2}$ with pulseoximetric curve;

4. Breathing in/out volume;

5. $\mathrm{FiO}_{2}$;

6. $\mathrm{EtCO}_{2}$;

7. Breathing rate (BR);

8. Breathing circuit tightness;

9. BIS monitoring by means of Aspect - 2000 or Vista, Aspect Med. Inc. (USA).

The transcranial oximetry was performed by means of ForeSight device (Casmed, USA). A reduction of $\mathrm{SrO}_{2}$ to a $20 \%$ lower level for 3 minutes or more, observed after anesthetic induction before the operation beginning in the conditions of stable hemodynamics and at $\mathrm{SpO}_{2} 98-100 \%$ was considered to be a cerebral hypoxemia case (event). At $\mathrm{SrO}_{2}$, we acted in accordance with the following algorithm:

- $\quad$ one-time hypotension (reduction of ABPavrg. by $10 \%$ or more relative to the outcome) without hemorrhage - noradrenaline infusion with an initial dose of $0.3 \mathrm{mg} / \mathrm{kg}$ and increase of $\mathrm{FiO}_{2}$ to 0.9 ;

- hypotension as a result of hemorrhage occurrence increase in the rate and change of the quality composition of the infused solutions and increase of $\mathrm{FiO}_{2}$ to 0.9 ;

- $\quad$ if the cause of $\mathrm{SrO}_{2}$ reduction cannot be established increase of $\mathrm{FiO}_{2}$ to 0.9 and change of ventilation parameters to increase $\mathrm{ETCO}_{2}$ to $50 \mathrm{mmHg}$.

To determine the content of $\mathrm{S} 100 \mathrm{~b}$ protein, as a marker of neuronal injury [39] venous blood samples were taken before the induction and subsequently 24 and 48 hours after the end of the operation only in those patients in whom cerebral hypoxemia event were discovered in the process of anesthesia.

The POD diagnosis was performed by CAM-ICU method $[40,41]$ on the $1^{\text {st }}-3^{\text {rd }}$ day of the postoperative period; and POCD was diagnosed by neuro-psychological testing with the aid of a MOCa-test [38, 42]. 
Таблица 2. Некоторые антропометрические и демографические данные обследованных больных Table 2. Anthropometric and demographic information of the patients under study

\begin{tabular}{lc}
\hline Parameters & Parameter values \\
\hline Number of patients, $n$ & 48 \\
Men/women, $n$ & $22 / 26$ \\
Coexistent CHD, \% & 67 \\
Coexistent essential hypertension, \% & 86 \\
Coexistent COPD, \% & 13 \\
Coexistent COLD, \% & 15 \\
ASA1 & - \\
ASA II & - \\
ASA III, \% & 17 \\
ASA IV, \% & 83 \\
ASA V, \% & - \\
\hline
\end{tabular}

Note (примечание): Parameters - показатели; Parameter values, $n \%$ - значение показателей, $n \%$; number of patients - число больных; меn - мужчины; women - женщины; coexistent CHD (ichemic heart disease) - сопутствующая ИБС (ишемическая болезнь сердца); coexistent essential hypertension - coпутствующая гипертоническая болезнь; coexistent COPD (cronic obstructive pulmonary disease) - сопутствующая хроническая обструктивная болезнь легких; coexistent COLD (chronic nonspecific lung disease) - сопутствующее хроническое неспецифическое заболевание легких; ASA1 - ASAV шкала Американской ассоциации анестезиологов ASA для оценки тяжестит состояния больного.

- при одномоментной гипотензии (снижение АДср. на $10 \%$ и более по отношению к исходу) без кровотечения инфузия норадреналина в начальной дозе 0,3 мкг/кг и увеличение $\mathrm{FiO}_{2}$ до 0,9;

- $\quad$ при гипотензии в результате возникшего кровотечения - увеличение темпа и изменение качественного состава инфузируемых растворов и увеличение $\mathrm{FiO}_{2}$ до 0,9 ;

- если причину снижения $\mathrm{SrO}_{2}$ не удавалось установить - увеличение $\mathrm{FiO}_{2}$ до 0,9 и изменение параметров вентиляции, предполагающие рост $\mathrm{ETCO}_{2}$ до 50 мм рт. ст.

Для определения содержания белка S100b, как маркера нейро-повреждения [39] пробы венозной крови брали до индукции и далее через 24 и 48 часов после окончания операции только у тех больных, у которых в процессе анестезии были выявлены события церебральной «гипоксемии».

Некоторые антропометрические данные больных представлены в табл. 2 .

Распределение больных в зависимости от характера выполненных операций представлено на рис. 1.

Диагностику ПОД проводили методом CAM-ICU [40, 41] на 1-е и 3-и сутки послеоперационного периода; ПОКД - на основании нейро-психологического тестирования с помощью MOCa-test [38, 42].

С целью последующей нейро-психологической оценки с использованием методики стандартизации [43] была создана контрольная группа, в которую вошло 47 добровольцев из числа прикрепленного контингента ведомственной поликлиники и родственников пациентов, принимавших участие в исследовании. Набор группы контроля в данном случае целесообразен по причинам:

1. Минимизация «эффекта запоминания» [22, 44].

2. В сегменте пациентов с сопутствующими ЦВЗ процессы отрицательной динамики закономерны и в некоторых случаях снижение когнитивного статуса может быть не связано с периоперационными факторами.

В исследуемой группе, на каждом этапе исследования: 7 дней, 1 месяц, 3 месяца, 6 месяцев, 1 год, - результаты МоСАtest подвергались процедуре стандартизации на основе аналогичных нейро-психологических показателей, определенных в те же сроки у контрольной группы. Полученный результат ис-

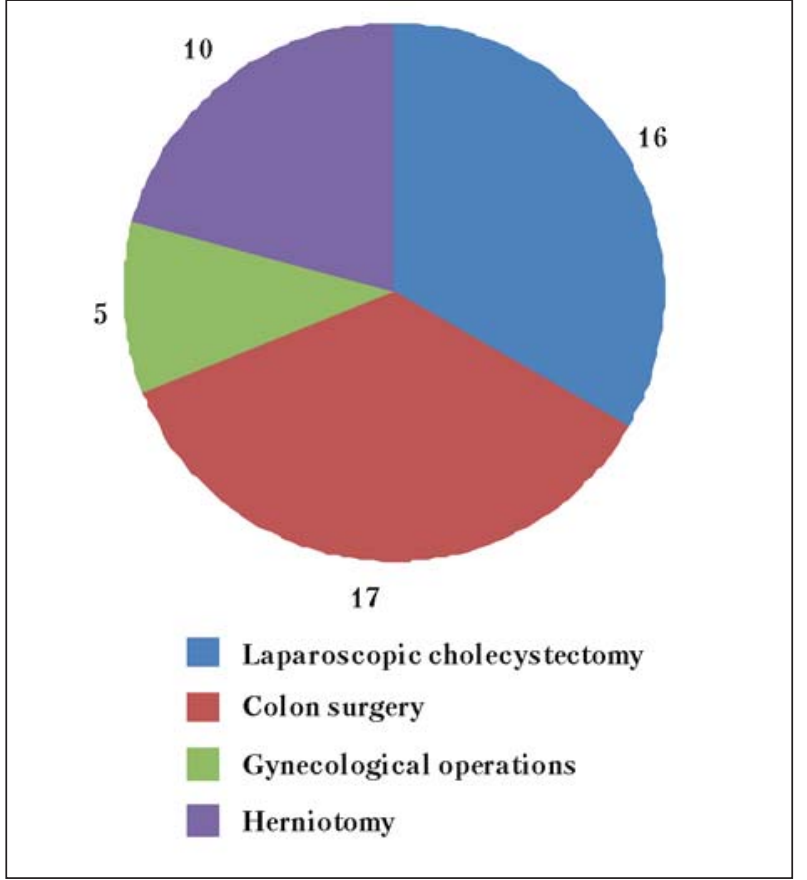

Рис. 1. Распределение больных в зависимости от характера выполненных операций

Fig. 1. Distribution of patients according to the character of operations performed

Note (примечание): laparoscopic cholecystectomy - лапароскопическая холецистэктомия; colon surgery - операции на кишечнике; gynecological operations - гинекологические операции; herniotomy - удаление грыжи.

For the purpose of subsequent neuro-psychological evaluation with the use of standardization methods [43], a reference group was created that included 47 volunteering individuals from the local community area and relatives of the patients participating in the study. In this case, the reference group recruitment is expedient for the following reason:

1. Minimization of the «memory effect» $[22,44]$

2. In the segment of patients with coexistent CVDs, the negative dynamics processes are natural, and in some cases the cognitive status reduction may not be connected with perioperative factors.

At every study stage (7 days, 1 month, 3 months, 6 months, 1 year ) the results of a MoCA-test were standardized on a base of similar neuro-psychological indicators determined in the reference group for the same time periods. Obtained result was used for detecting POCD and evaluating its gravity. The Z-score equal or exceeding 1.96 evidenced a deviation from the norm, i.e., of developing POCD; a greater value corresponded to a greater gravity of dysfunction.

For forecasting the standardized indicators determining a severe degree of POCD, a logistic regression model was used, in which the Z-score variables at all stages of the study were included in one whole and reduced to a binary index (POCD event - 1 ; absence of POCD - 0). After that, the least square method was used to conduct the procedure of logistic regression with one variable in the form of the said indexes; this analysis resulted in a POCD event with probability of at least $95 \%$.

Statistical analysis.

The statistical processing of the results obtained was made using MedCalc 7 software, StatPlus 2009 Professional. The variables obtained during the neuro-psychological testing were standardized [43]. The results were further processed to perform Spearman rank order correlation, logistic regression, ROC analysis, and comparison of frequencies of binary qualitative characters in both groups. 
пользовали для выявления ПОКД и оценки ее тяжести. Z-оценка равная и превышающая 1.96 свидетельствовала об отклонении от нормы, то есть о развитии ПОКД, больший показатель соответствовал большему значению тяжести дисфункции.

Для предсказания стандартизированных показателей, определяющих тяжелую степень ПОКд, использовалась логистическая регрессионная модель, в которой переменные Z-оценок на всех этапах исследования включены в одну совокупность и приведены к бинарному показателю (событие ПОКД-1, отсутствие ПОКД-0). В дальнейшем методом наименьших квадратов проведена процедура логистической регрессии с одной независимой переменной в виде указанных показателей, результатом этого анализа явилось событие ПОКД с вероятностью не менее $95 \%$.

Статистический анализ. Статистическая обработка полученных результатов проводилась с использованием программ Statistica 7, MedCalc, StatPlus 2009 Professional. Переменные, полученные при нейро-психологическом тестировании подвергнуты стандартизации [43]. Обработка результатов проведена при помощи статистических моделей: ранговая корреляция Спирмена, логистическая регрессия, ROC-анализ, сравнение частот бинарных качественных признаков в двух группах.

\section{Результаты и обсуждение}

Средние периоперационныепоказатели гемодинамики отражены на рис. 2.

В ходе анестезиологического пособия в указанной выборке больных артериальной гипертензии не зарегистрировано. Некоторая тенденция к тахикардии, вероятно, является закономерным компенсаторным ответом симпатической нервной системы на введение анестетика и ответом на применение норадреналина, применяемым как для лечения гипотензии, так и при алгоритме лечения церебральноой гипоксемии.

Событием гипотензии считалось снижение среднего артериального давления на $20 \%$ от исходного в течении 5 минут, данное состояние отмечено у 15 пациентов $(31,2 \%)$.

Пульсоксиметрия позволила выявить эпизоды умеренной гипоксемии, ранее описанный алгоритм привел к нормализации ситуации у большинства больных, однако, у 3 больных (6,2\%) хирургическое вмешательство сопровождалось системной десатурацией, с последующими показателями сатурации 90-92\%, закономерно, что у этих пациентов системная гипоксемия сопровождалось церебральной десатурациенй.

Церебральная гипоксемия отмечена у 22 (45,8\%) больных, при этом событие гипотонии былодостоверно связано с показателями $\mathrm{SrO}_{2}(r=-0,33 ; p<0,05)$, с большей силой подобная корреляционная связь проявилась в отношении показателя $\mathrm{SpO}_{2}(r=0,56 ; p<0,05)$. Однако следует отметить, что при проведении множественного регресионного анализа распределение влияния периоперационных факторов на выраженность когнитивных расстройств указывает, что независимыми предикторами формирования послеоперационных когнитивных нарушений явились: степень дооперационных когнитивных нарушений, а более значимым, глубина и выраженность интраоперационной церебральной десатурации. Так стандартизованный коэффициент регрессии (beta) для показателя церебральной

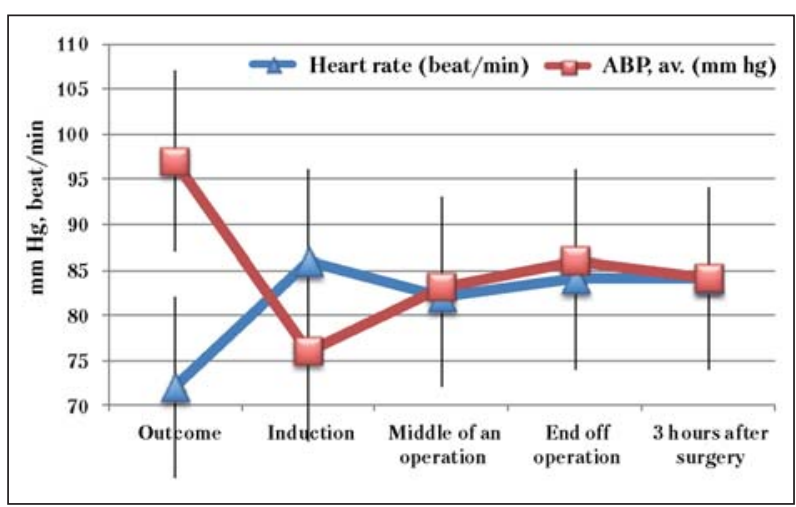

Рис. 2. Средние периоперационные показатели гемодинамики. Fig. 2. Average perioperative hemodynamics indicators.

Note (примечание): heart rate (beat/min) - число сердечных сокращений (уд./мин); ABP, av - average blood pressure (mm Hg) - среднее артериальное давление (мм рт. ст.); outcome исход; induction - индукция; middle of an operation - середина операции; end of operation - конец операции; 3 hours after surgery - 3 ч после операции.

\section{Results and Discussion}

Average perioperative hemodynamics indicators are shown in Figure 2.

In course of the anaesthetic support in the specified sampling, no patients with arterial hypertension were registered. Probably, some tendency to tachycardia is a regular compensatory response of the sympathetic nervous system to anesthetic induction and response to noradrenalin infusion which is used for the hypotension treatment and in the algorithm of cerebral hypoxemia treatment.

A hypoxemia event was a reduction of average ABR by $20 \%$ in comparison with the outcome during 5 minutes, it was noted in 15 patients $(31.2 \%)$.

Pulse oximetry allowed detecting the events of moderate hypoxemia, the algorithm described earlier resulted in the normalization of the condition of many patients; however, the surgical intervention of 3 patients $(6.2 \%)$ was accompanied by system desaturation with further saturation indicators of 90-92\%. Expectedly, system hypoxemia in patients was accompanied by cerebral desaturation.

Cerebral hypoxemia was found in 22 patients (45.8\%) in which the hypotension event was negatively correlated with $\mathrm{SrO}_{2}$ indicators $(r=-0.33 ; p<0.05)$ and a positive correlation was found in relation to $\mathrm{SpO}_{2}$ indicators $(r=0.56 ; p<0.05)$. However, it should be noted that, by conducting the multiple regressive analysis, a distribution of influence of the perioperative factors on the intensity of cognitive disturbances shows that the independent predicators of the formation of postoperative cognitive disturbances included: a degree of preoperative cognitive disturbances and depth and intensity of intraoperative cerebral desaturation. Thus the standardized regression coefficient (beta) for the indicators of cerebral saturation on the $7^{\text {th }}$ day and $30^{\text {th }}$ day of the study and after 3 months was 0.47 , -0.53 and -0.51 , correspondingly, and in case of the analysis of influence on POD $r=-0.53$, the final indicators are shown in the Table 3. 
Таблица 3. Взаимосвязь и степень воздействия различных периоперационных показателей на выраженность послеоперационных когнитивных нарушений.

Table 3. Interconnection and influence of different perioperative indicators on the intensity of cognitive disturbances at different stages.

\begin{tabular}{|c|c|c|c|c|c|c|}
\hline Parameters on stages of study & Perioperative factor & beta & $t(d f)$ and $p(t)$ & $\boldsymbol{R}$ & $\overline{\mathbf{R}^{2}}$ & $\boldsymbol{P}$ \\
\hline \multirow[t]{4}{*}{ POD (CAM-ICU) } & MCI & 0.2 & $1.62(p>0.05)$ & 0.7 & 0.49 & $p<0.05$ \\
\hline & Hypotension & -0.18 & $-1.48(p>0.05)$ & & & \\
\hline & $\mathrm{SpO}_{2}$ & -0.31 & $-2.01(p>0.05)$ & & & \\
\hline & $\mathrm{SrO}_{2}$ & -0.53 & $-3.71(p<0.05)$ & & & \\
\hline \multirow[t]{4}{*}{ POCD (MOCa-test) 7 days } & $\mathrm{MCI}$ & 0.06 & $0.45(p>0.05)$ & 0.59 & 0.35 & $p<0.05$ \\
\hline & Hypotension & -0.23 & $-1.70(p>0.05)$ & & & \\
\hline & $\mathrm{SpO}_{2}$ & -0.20 & $-1.14(p>0.05)$ & & & \\
\hline & $\mathrm{SrO}_{2}$ & -0.47 & $-2.95(p<0.05)$ & & & \\
\hline \multirow[t]{4}{*}{ POCD (MOCa-test) 30 days } & $\mathrm{MCI}$ & 0.29 & $2.64(p<0.05)$ & 0.76 & 0.58 & $p<0.05$ \\
\hline & Hypotension & -0.05 & $-0.51(p>0.05)$ & & & \\
\hline & Saturation & -0.19 & $-1.35(p>0.05)$ & & & \\
\hline & $\mathrm{SrO}_{2}$ & -0.53 & $-4.09(p<0.05)$ & & & \\
\hline \multirow[t]{4}{*}{ POCD (MOCa-test) 3 months } & MCI & 0.33 & $2.94(p<0.05)$ & 0.77 & 0.59 & $p<0.05$ \\
\hline & Hypotension & 0.00 & $0.001(p>0.05)$ & & & \\
\hline & $\mathrm{SpO}_{2}$ & -0.19 & $-1.27(p>0.05)$ & & & \\
\hline & $\mathrm{SrO}_{2}$ & -0.51 & $-3.81(p<0.05)$ & & & \\
\hline \multirow[t]{4}{*}{ POCD (MOCa-test) 6 months } & $\mathrm{MCI}$ & 0.68 & $5.90(p<0.05)$ & 0.8 & 0.64 & $p<0.05$ \\
\hline & Hypotension & 0.03 & $0.30(p>0.05)$ & & & \\
\hline & $\mathrm{SpO}_{2}$ & -0.07 & $-0.47(p>0.05)$ & & & \\
\hline & $\mathrm{SrO}_{2}$ & -0.23 & $-1.87(p>0.05)$ & & & \\
\hline \multirow[t]{4}{*}{ POCD (MOCa-test) 1 year } & $\mathrm{MCI}$ & 0.77 & $7.10(p<0.05)$ & 0.84 & 0.7 & $p<0.05$ \\
\hline & Hypotension & -0.08 & $-0.8(p>0.05)$ & & & \\
\hline & $\mathrm{SpO}_{2}$ & -0.1 & $-0.74(p>0.05)$ & & & \\
\hline & $\mathrm{SrO}_{2}$ & -0.11 & $-0.96(p>0.05)$ & & & \\
\hline
\end{tabular}

Note (примечание): Parameters on stages of study - показатели на этапах исследования; Реrioperative factor - периоперационный фактор; beta (standardized regression coefficient) - бета (стандартизованный коэффициент регрессии); POD (роstoperative delirium) - послеоперационный делирий; POCD (postoperative cognitive dysfunction) - послеоперационная когнитивная дисфункция; Hypotension - гипотензия; MCI (degree of preoperative cognitive disturbances) - степень преоперационных когнитивных нарушений; day - день, months - месяцы; $\mathrm{SpO}_{2}$ - (saturation) - насыщение крови кислородом; SrO 2 (level of cerebral saturation) - уровень церебральной сатурации; MOCa-test (Montreal cognitive assessment scale) - Монреальская шкала когнитивной оценки; CAM-ICU - confusion assessment method for the intensive care unit - метод оценки спутанности сознания для интенсивной терапии; R (coefficient of multiple correlation) - коэффициент множественной корреляции; $\mathrm{R}^{2}$ ( determination coefficient) - коэффициент детерминации; $\mathrm{t}(\mathrm{df})$ and $\mathrm{p}(\mathrm{t})$ is Student criteria and the error of a probability of a hypothesis about equality of zero in an absolute term of regression equation - критерий Стьюдента и вероятность ошибки гипотезы о равенстве нулевого свободного члена регрессионного уравнения: $P$ is a level of significance of the regression model - уровень значимости регрессионной модели.

сатурации на 7-й, 30-й дни исследования и 3 месяца составил соответственно: $-0,47 ;-0,53 ;-0,51$, а в случае анализа влияния на ПОД - 0,53 окончательные значения регрессии указаны в табл. 3 .

Дальнейшее изучение влияния церебральной гипоксии привело к следующим результатам.

Частота развития послеоперационного делирия составила 43,7\%.Умеренная отрицательная корреляционная связь между изменениями $\mathrm{SrO}_{2}$ и изменениями когнитивного статуса появилась только (рис. 2) на 30 сутки исследования $(r=-0,47 ; p<0,05)$. Указанные взаимоотношения сохранялись и на этапе «3 месяца» $(r=-0,51 ; p<0,05)$.

Сильная отрицательная корреляция содержания белка $\mathrm{S} 100 \mathrm{~b}$ с величиной $\mathrm{SrO}_{2}$ отмечена на всех этапах, начиная с «7 дней п/о» $(r=-0,87 ; p<0,05)$. Предполагая высокую прогностическую ценность теста определения содержания белка S100b, для изучения связи между уровнем этого маркера нейро-повреждения и событием ПОД нами проведен раздельный логистический регрессионный анализ (рис. 3), в который вошли событие ПОД, как зависимая бинарная переменная откли-
Further studies revealed that the frequency of development of postoperative delirium was $43.7 \%$. A moderate negative correlative connection between the changes of $\mathrm{SrO}_{2}$ and changes of cognitive status appeared only on $30^{\text {th }}$ day of the study ( $r=-0.47 ; p<0.05$, Fig. 2$)$. The specified relations were also evident in 3 months after the study $(r=-0.51 ; p<0.05)$.

A strong negative correlation of the content of S100b protein with $\mathrm{SrO}_{2}$ was detected at all stages starting from 7 days after the surgery $(r=-0.87 ; p<0.05)$. Suggesting a high prognostic value of the test for detecting concentration of $\mathrm{S} 100 \mathrm{~b}$ protein in neuroinjury and the POD, theseparate logistic regression analysis was performed (Fig. 3)/ In this study, the POD event was considered as a dependant binary response variable $(1-$ presence of POD, $0-$ absence of POD) and the content of $\mathrm{S} 100 \mathrm{~b}$ protein served as an independent permanent variable. The compatibility level of the model of regression $\chi^{2}$ amounted to -10.63 ; the importance level amounted to $(p<0.05)$.

In order to detect the optimal parameters of the prognostic value of the marker of neuro-injury, ROC 


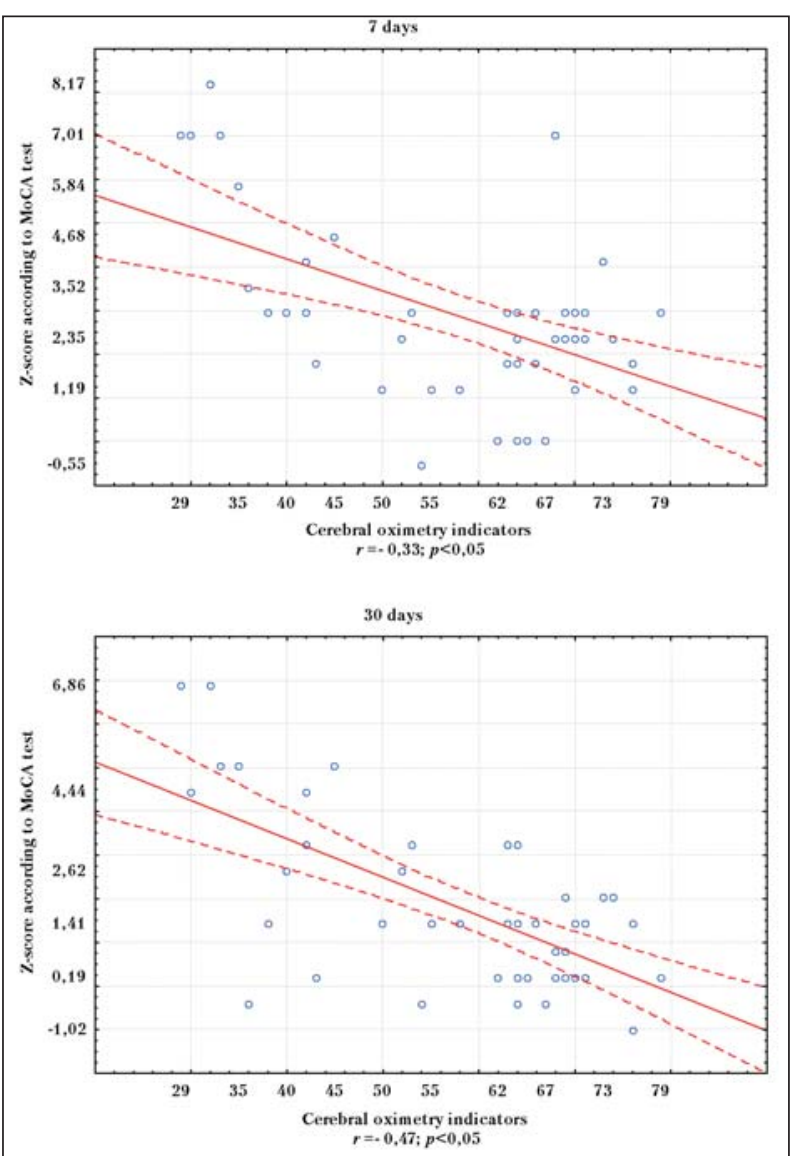

Рис. 3. Корреляция церебральной сатурации $\left(\mathrm{SrO}_{2}\right)$ и стандартизированных показателей нейро-психологического тестирования на 7 и 30 сутки исследования.

Fig. 3. Correlation of cerebral saturation $\left(\mathrm{SrO}_{2}\right)$ values and standardized indexes of neuro-psychological testing on the $7^{\text {th }}$ and $30^{\text {th }}$ days of the study.

Note (примечание): Z-score according to MoCA test - оценка по шкале MoCA; cerebral oximetry indicators - показатели церебральной оксиметрии; days - дни.

ка (1 - наличие ПОД, 0 - отсутствие ПОД) и содержание белка S100b, как независимая непрерывная переменная. Уровень согласованности модели регрессии $\chi^{2}$ составил $-10,63$; уровень значимости $(p<0,05)$.

С целью определения оптимальных параметров прогностической значимости маркера нейро-повреждения в дальнейшем проведен ROC-анализ и определен оптимальный порог отсечения (optimalcut-offvalue) по таблице массива точек максимальная суммарная чувствительность и специфичность модели, т. е. Se+Sp - это $\mathrm{S} 100 \mathrm{~b}>0,27 \mathrm{нг} /$ мл. При этом чувствительность составляла $68,7 \%$ (95\% ДИ от 41,4 до 88,9$)$, т.е. у $41,4-88,9 \%$ пациентов с делирием $\mathrm{S} 100 \mathrm{~b}>0,27$, а специфичность равна $100 \%$ (95\% ДИ 54,1-100), то есть у 54,1-100\% пациентов без делирия $\mathrm{S} 100 \mathrm{~b}<0,27$ нг/мл баланс между чувствительностью и специфичностью, т.е. когда $\mathrm{Se} \approx \mathrm{Sp}-$ это $\mathrm{S} 100 \mathrm{~b}>0,24 \mathrm{Hг} /$ мл. Чувствительность равна $75 \%$ (95\% ДИ от 47,6 до 92,6), специфичность равна 83,3\% (95\% ДИ от 36,1 до 97,2).

При графическом анализе ROC-кривой (рис. 4) отмечается, что точка, соответствующая $\mathrm{Se} \approx \mathrm{Sp}$ имеет наиболее ближнее положение к левому верхнему углу. Та-

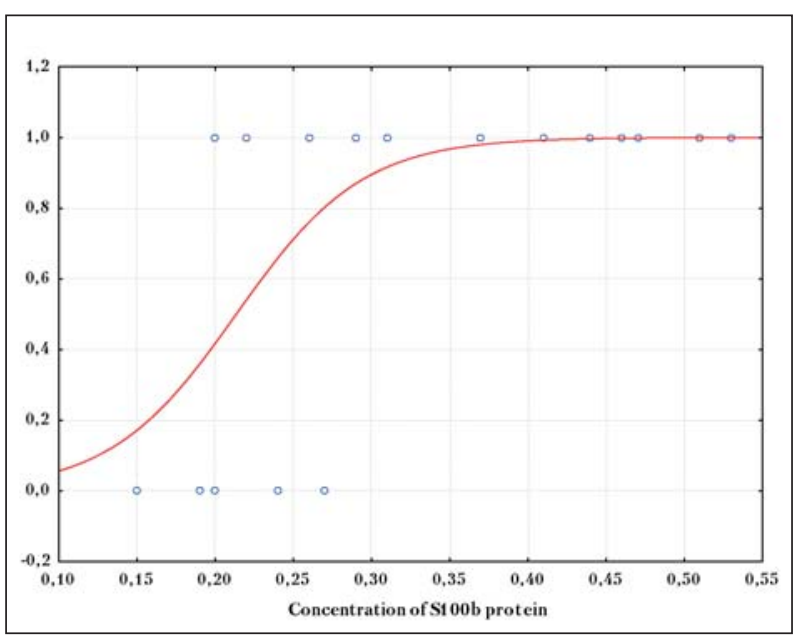

Рис. 4. Модель логистической регрессии вероятности события послеоперационного делирия от уровня белка S100b. Fig. 4. The model of logistic regression of the probability of the

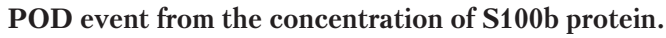

Note (примечание): concentration of S100b protein - концентрация белка S100b; POD (postoperative delirium) - послеоперационный делирий.

analysis was conducted and the optimal cut-off value of S100b was defined as $>0.27 \mathrm{ng} / \mathrm{ml}$ with sensitivity $68.7 \%$ ( $95 \%$ DI from 41.4 to 88.9 , i.e. $41.4-88.9 \%$ of the patients with delirium had $\mathrm{S} 100 \mathrm{~b}>0.27$ ) and the specificity $100 \%$ (95\% DI $54.1-100$, i.e. $54.1-100 \%$ of the patients without delirium $\mathrm{S} 100 \mathrm{~b}<0.27 \mathrm{ng} / \mathrm{ml}$ ).

At $\mathrm{S} 100 \mathrm{~b}>0.24 \mathrm{ng} / \mathrm{ml}$,te the sensitivity was $75 \%$ (95\% DI from 47.6 to 92.6 ) and specificity was 83.3\% (95\% DI from 36.1 to 97.2 ).

Analysis of ROC curves (Fig. 4) showed that the point, correlating to $\mathrm{Se} \approx \mathrm{Sp}$, had the closest position to the left upper corner. Thus, the choice of the most optimal cutoff value by prediction of the POD event is mostly required the value of $\mathrm{S} 100 \mathrm{~b}>0.24 \mathrm{ng} / \mathrm{ml}$. At a latter cutoff value, the area under ROC curve was a marker of prognostic efficiency equal to 0.9 (SE 0.07 ; DI $95 \%$ from 0.69 to 0.98 ) that characterized the prognostic value of ROC analysis as an excellent classifier.

The depth and intensity of intraoperative cerebral desaturation during 6 months of postoperative period was the main determining factor of POCD (table 4), so the number of the patients with POCD on the $7^{\text {th }}$ day of postoperative period reached $72.7 \%$, whereas after 1 month it was decreased to $40.9 \%$, after 3 months decreased to $36.4 \%$, after 6 months - decreased to $17.6 \%$ / E even after 1 year this indicator was equal to $17.6 \%$.

The test for the detection of the content of S100 b protein in blood plasma of the patients was also informative for the prediction of the POCD development in case of indeliberate cerebral desaturation. So, there was a strong correlation on the $7^{\text {th }}$ day $(r=0.68 ; p<0.05)$. The prognostic value of the test remained significant during the study up to 6 months of postoperative period (table 7 ).

As in the cases of delirium, we have studied the correlation between the concentration of S100b protein and the POCD event with the aid of logistic regression analysis. 
Таблица 4. Частота наблюдения послеоперационных когнитивных дисфункций на этапах исследования у больных с церебральной десатурацией.

Table 4. The frequency of postoperative cognitive disfunction (POCD) in patients with cerebral desaturation.

\begin{tabular}{lccc}
\hline Stages of study & $\boldsymbol{n}$ & POCD & \% \\
\hline 7 days & 22 & 16 & 72.7 \\
30 days & 22 & 9 & 40.9 \\
3 months & 21 & 8 & 36.4 \\
6 months & 17 & 3 & 17.6 \\
1 year & 17 & 3 & 17.6 \\
\hline
\end{tabular}

Note (примечание): Stages of study - этапы исследования; $n-$ число больных; days - дни; months - месяцы; year - год.

Таблица 5. Корреляционная связь уровня белка S100b с выраженностью когнитивного повреждения на этапах исследования.

Table 5. The correlation of the content of S100b protein with the intensity of cognitive disturbances at the research stages.

\begin{tabular}{lcc}
\hline Stages of study & $\begin{array}{c}\text { Correlation } \\
\text { coefficient }(\boldsymbol{r})\end{array}$ & Significance $(\boldsymbol{p})$ \\
\hline 7 days & 0.68 & $p<0.05$ \\
30 days & 0.71 & $p<0.05$ \\
3 months & 0.74 & $p<0.05$ \\
6 months & 0.66 & $p<0.05$ \\
1 year & 0.43 & $p<0.05$ \\
\hline
\end{tabular}

Note (примечание): Stages of study - этапы исследования; Correlation coefficient $(r)$ - коэффициент корреляции; Significance - уровень значимости; days - дни; months месяцы; year - год.

ким образом, выбор наиболее оптимального порога отсечения (optimalcut-offvalue) при предсказании ПОД скорее целесообразен для критерия S100b>0,24 нг/мл. При этом площадь под ROC-кривой как маркер прогностической эффективности составила 0,9 (SE 0,07; ДИ 95\% от 0,69 до 0,98), что характеризует прогностическую ценность ROC-анализа, как отличный классификатор.

Глубина и выраженность интраоперационной церебральной десатурации на протяжении 6 месяцев послеоперационного периода являлась основным определяющим фактором течения ПОКД (табл. 4), так количество пациентов с ПОКД на 7 сутки послеоперационного периода составило $72,7 \%$; через 1 месяц уменьшилось до 40,9\%, через 3 месяца до 36,4\%, через полгода 17,6\%, и, даже через год, этот показатель оставался на уровне 17,6\%.

Тест на содержание белка S100 b в плазме крови больных оказался информативным и для прогноза развития ПОКД в случае непреднамеренной церебральной десатурации. Так на 7 сутки наблюдалась сильная корреляционная связь $(r=0,68 ; p<0,05)$. Прогностическое значение теста сохранялось на протяжении исследования до 6 месяцев послеоперационного периода (табл. 5)

Также как в случае с делирием, нами изучена связь между уровнем белка S 100b и событием ПОКд, с помощью логистического регрессионного анализа. Статистически значимая корреляция отмечена на всех этапах, начиная с «30 дней после операционного периода» (рис. 6, табл. 6).

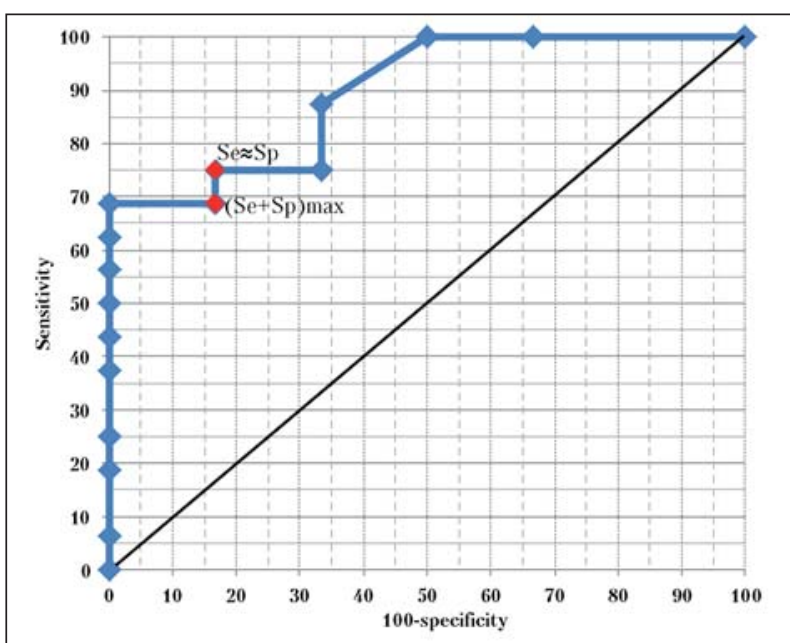

Рис. 5. ROC-кривая предсказания событий послеоперационного делирия в зависимости от уровня белка S100b.

Fig. 5. ROC prediction of the postoperative deliriume event depending on the concentration of $\mathrm{S100b}$ protein.

Note (примечание): sensitivity (Se) - чувствительность; specificity (Sp) - специфичность; $(\mathrm{Se}+\mathrm{Sp}) \mathrm{max}$ - максимальные значения специфичности и чувствительности.

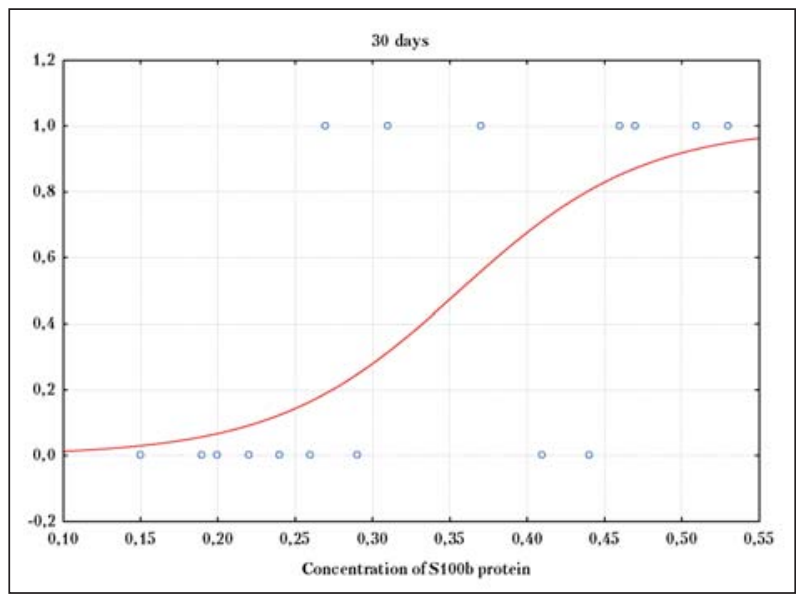

Рис. 6. Зависимость вероятности события ПОКД от уровня белка S100b на 30 сутки исследования (модель логистической регрессии).

Fig. 6. Dependence of POCD event on S100b protein level on the 30th day of the study (logistic regression model).

Note (примечание): Concentration of S100b protein - концентрация белка S100b; days - дни; POCD (postoperative cognitive dysfunction) - послеоперационная когнитивная дисфункция.

Statistically significant correlation was noted in all stages starting from 30 days after the surgery (Fig. 6; Table 8).

ROC-analysis determined the optimal cut-off value for $\mathrm{S} 100 \mathrm{~b}$ as determined by maximal sensitivity and specificity within the model (i.e. $\mathrm{Se}+\mathrm{Sp}$ ) was $>0.26 \mathrm{ng} / \mathrm{ml}$ (Fig. 7). At the same time, the sensitivity was $100 \%$ (95\% DI from 66.2 to 100$)$ and the specificity was equal to $76.9 \%$ (95\% DI from 42.2 to 94.7$)$. The area under the curve as a marker of prognostic efficiency was 0.94 (SE 0.05 ; DI $95 \%$ from 0.75 to $0.99)$ demonstrating an excellent prognostic value.

During the year, there were 2 fatal cases in the specified group due to acute myocardial infarction and ischemic stroke, and 3 cases of the development of stable 
Таблица 6. Оценка значимости влияния уровня белка $\mathrm{S} 100 \mathrm{~b}$ на событие послеоперационной когнитивной дисфункции в модели бинарной логистической регрессии на различных этапах исследования.

Table 6. Significanceof the influence of the $S 100 b$ protein content on the postoperative cognitive disfunction event in the model of binary logistic regression.

\begin{tabular}{lcc}
\hline Stages of study & $\begin{array}{c}\text { Compatibility level } \\
\text { of the regression } \\
\text { model, } \boldsymbol{\chi}^{2}\end{array}$ & Significance $(\boldsymbol{P})$ \\
\hline 7 days & 2.79 & $>0.05$ \\
30 days & 13.67 & $<0.05$ \\
3 months & 7.56 & $<0.05$ \\
6 months & 6.54 & $<0.05$ \\
1 year & 5.67 & $<0.05$ \\
\hline
\end{tabular}

Note (примечание): stages of study - этапы исследования; compatibility level of the model of regression, $\chi^{2}-$ уровни совместимости по значению $\chi^{2}$; days - дни; months - месяцы; year - год.

B ходе проведения ROC-анализа (рис. 7) оптимальная точка отсечения выбрана по принципу максимальной суммарной чувствительность и специфичности модели, т. е. Se+Sp, и оказалась равной $\mathrm{S} 100 \mathrm{~b}>0,26$ нг/мл, при этом чувствительность равна $100 \%$ (95\% ДИ от 66,2 до 100), специфичность равна 76,9\% (95\% ДИ от 42,2 до 94,7).Площадь под ROC-кривой как маркер прогностической эффективности составила 0,94 (SE 0,05; ДИ 95\% от 0,75 до 0,99), что указывает на отличную прогностическую ценность.

В течение года по разным причинам в исследуемой группе отмечены 2 летальных исхода, вследствие острого инфаркта миокарда и острого нарушения мозгового кровообращения по ишемическому типу соответственно, а так же 3 случая развития стойкой деменции. Результаты исследования этих пациентов носили не полный характер, учтены в анализе до момента наступления смерти или заболевания, а на следующих этапах цензурированы.

Итак, у больных с церебро-васкулярным заболеванием, даже, относительно кратковременное снижение $\mathrm{SrO}_{2}$ приводило к развитию ПОД в $72,7 \%$ случаев, к развитию ПОКД, так же, в 72,7\%. Обнаруженная корреляционная связь свидетельствует в пользу высказанного предположения о наличие взаимосвязи и взаимозависимости между ПОД и ПОКД. Однако количественная характеристика данной связи - «умеренно выраженная» - заставляет искать иные ранние симптомы ПОКд.

Высокая корреляционная зависимость концентрации белка S100b с частотой развития ПОД и ПОКд, позволяет считать данный показатель чувствительным и специфичным предиктором развития обсуждаемых состояний. Возможно, отсутствие корреляции на первом этапе ( «7 дней п/о») связано с тем, что в структуре ранних послеоперационных когнитивных нарушений имеется часть так называемых краткосрочных когнитивных отклонений $[44,45]$. В противоположность этому, считается, что выявление ПОКД позднее, в восстановительном периоде (около 4 недель после операции),

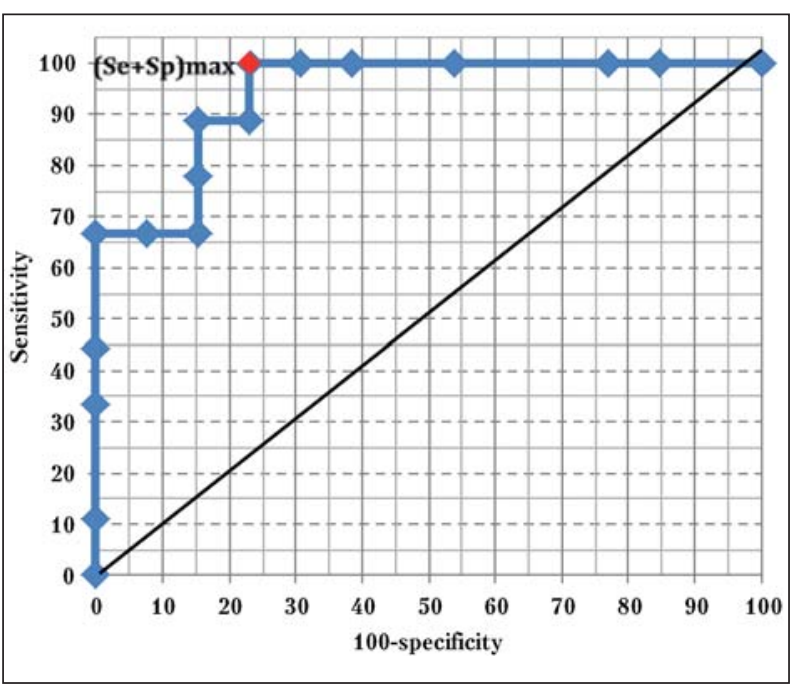

Рис. 7. ROC-кривая предсказания события послеоперационной когнитивной дисфункции в зависимости от уровня белка S100b.

Fig. 7. Postoperative cognitive disfunction event probability depending on S100b protein level (ROC analysis).

Note (примечание): sensitivity - чувствительность; specificity специфичность; ( $\mathrm{Se}+\mathrm{Sp}) \mathrm{max}$ - максимальные значения специфичности и чувствительности.

dementia. The data were taken into account until death of patients and the next stages they were censored.

Thus, even a short-term reduction of $\mathrm{SrO}_{2}$ in the patients with cerebrovascular disease resulted in the development of both POD and POCD in $72.7 \%$ of the cases. The detected correlation confirmed the hypothesis about the interconnection and interdependence of POD and POCD. However, the quantitative characteristic of such connection as «moderately expressed» resulted in paying attention to other precursory symptoms of POCD.

A high correlative dependence of the concentration of S100b protein on the frequency of the development of POD and POCD allows considering this indicator as a sensitive and specific predictor of their development. Probably, the absence of correlation at the first stage ( 7 days after the operation) was due to developing short-term cognitive deviations in the structure of early postoperative cognitive disturbances $[44,45]$. In contrast, it was considered that the detection of POCD later at the rehabilitation period (nearly 4 weeks after the operation) had a «real»character [44]. Probably, the differences of the correlation indicators between the level of cerebral saturation $\left(\mathrm{SrO}_{2}\right)$ and the severity of POCD in the agreed period are similarly connected.

The concentration of S100b protein in the blood of the patients with cerebrovascular diseases higher than 0.26 $\mathrm{ng} / \mathrm{ml}$ clearly demonstrates a high probability of the development of POD and POCD. POD and POCD are «the links of one chain», showing the disturbance of consciousness due to the diffuse brain lesion during the cases of cerebral hypoxemia. The presence of organic disturbances of CNS during delirium is connected with the definition of the discussed condition [13-15]. Most likely, one of the reasons of the development of POCD is also post-hypoxic encephalopathy. Other authors have mentioned it earlier [44, 46, 47]. 
скорее всего, имеет «истинный» характер [44]. С этим же, вероятно, связаны различия показателей корреляции между уровнем церебральной сатурации $\left(\mathrm{SrO}_{2}\right)$ и тяжестью ПОКД в обсуждаемые сроки.

Содержание белка S100b в крови больных с церебро-васкулярными заболеваниями, превышающее 0,26 нг/мл, указывает на высокую вероятность развития и ПОД и ПОКД. По-видимому, ПОД и ПОКД являются «звеньями одной цепи», проявлениями расстройства сознания вследствие диффузного поражения мозга во время эпизодов церебральной гипоксемии. Наличие органического повреждения ЦНС при делирии вытекает из определения обсуждаемого состояния [13-15]. По всей вероятности, по крайней мере, одной из причин развития ПОКД, также, является постгипоксическая энцефалопатия. Ранее на это указывали и другие авторы [44, 46, 47].

Исследование проведено с использование Z-анализа, что, несомненно, повышает его достоверность. Вместе с тем, работа имеет и ряд серьезных ограничений: старческий возраст и наличие ЦВЗ - всего лишь два из более, чем 60-ти известных предрасполагающих факторов к развитию ПОД и ПОКД [2, 22, 49, 50, 51, 53, 54], а церебральная гипоксемия - всего лишь один из многочисленных инициирующих механизмов нейро-повреждения [55]. Мы осознанно «сузили» круг пациентов, так как на основании уже имеющихся исследований, опубликованных в отечественных научных изданиях $[56,57]$ предположили, что именно у больных с ЦВЗ церебральная гипоксемия (в нашем случае, конечно же, непреднамеренная, крайне нежелательная, своевременно обнаруженная и леченная) обладает максимальным повреждающим воздействием. Мы рассчитывали, что данное обстоятельство позволит выполнить исследование в относительно небольшой группе больных и в сжатые сроки. Наши предположения подтвердились, но насколько можно переносить обнаруженные закономерности на общую популяцию больных, можно определить только в результате дальнейших исследований.

Малое количество больных не позволило установить взаимосвязь и взаимозависимость частоты развития ПОКД и годовой летальности, тем не менее, наличие подобной связи отмечено в нескольких независимых исследованиях других авторов [4-6, 58], а значит, обнаруженные закономерности диагностики и профилактики ПОД и ПОКД, можно использовать для снижения количества п/о осложнений и летальности у хирургических больных.

\section{Заключение}

У больных с церебро-васкулярными заболеваниями крайне опасны даже кратковременные эпизоды це-
The research was conducted with the help of the Zanalysis that, undoubtedly, increased its accuracy. However, the study had a number of serious restrictions: old age and presence of cerebrovascular diseases were only two of over than sixty known predisposing factors of the development of POD and POCD [2, 22, 49-51, 53, 54] whereas cerebral hypoxemia was the only one of various initiating mechanisms of neuro-injuries [55]. We consciously included limited the number of patients since (according to most Russian scientific publications [56, 57]) we assumed that the patients with cerebrovascular diseases had cerebral hypoxemia (in our case indeliberate, totally unacceptable, timely detected and cured) with a maximal affecting influence.

We considered that these circumstances would allow conducting the research in a relatively small group of patients and within the limited period. Our assumptions were proved, however, it would be necessary to determine, whether the defined regularities could be translated to a larger cohorts of patients in further studies.

A small cohort of patients did not allow establishing the interconnection and interdependence of the frequency of the development of POCD and annual mortality, although such connection was noted in several independent studies $[4-6,58]$. It means that the defined regularities of diagnostics and prevention of POD and POCD can be used for reducing the number of postoperative complications and mortality of patients post-surgery.

\section{Conclusion}

Even short-term episodes of cerebrovascular complications are extremely dangerous in the patients with cardiovascular diseases. In cases of short-term episodes of cerebrovascular events, there is a high possibility of the development of postoperative delirium and postoperative cognitive dysfunctions, and the quarter of the patients might have stable and refractory dysfunctions remaining even in a year after operation. The early predictor of postoperative cognitive dysfunction is rising concentration of S100b protein in the blood of the patients $0.26 \mathrm{ng} / \mathrm{ml}$ above the norm.

ребральной гипоксемии. При возникновении последних велика вероятность развития послеоперационного делирия и послеоперационной когнитивной дисфункции, причем, у четверти больных упорной и стойкой, сохраняющейся и через год после перенесенной операции. Ранним предиктором послеоперационной когнитивной дисфункции является рост содержания белка S100b в пробах крови больных выше порогового значения в 0,26 нг/мл.

References

1. Gendelman M. Postoperative nervous system dysfunction. Anaesthesia 2000; 55 (4): 113-119.

2. Monk T.G., Price C.C. Postoperative cognitive disorders. Curr. Opin. Crit. Care. 2011; 17 (4): 376-381. http://dx.doi.org/10. 1097/MCC. 0b013e328348bece. PMID: 21716111 
3. Rasmussen L.S., Larsen K., Houx P., Skovgaard L.T., Hanning C.D., Moller J.T.; ISPOCD group. The assessment of postoperative cognitive function. Acta Anaesthesiol. Scand. 2001; 45 (3): 275-289. http://dx.doi.org/10.1034/j.1399-6576.2001.045003275.x. PMID: 11207462

4. Price C.C., Garvan C.W., Monk T.G. Type and severity of cognitive decline in older adults after noncardiac surgery. Anesthesiology. 2008; 108 (1): 8-17. http://dx.doi.org/10.1097/01.anes.0000296072. 02527.18. PMID: 18156877

5. Robinson T.N., Raeburn C.D., Tran Z.V., Angles E.M., Brenner L.A., Moss $M$. Postoperative delirium in the elderly: risk factors and outcomes. Ann. Surg. 2009; 249 (1): 173-178. http://dx.doi.org/10.1097/SLA. 0b013e31818e4776. PMID: 19106695

6. SteinmetzJ., Christensen K.B., Lund T., Lohse N., Rasmussen L.S.; ISPOCD Group. Long-term consequences of postoperative cognitive dysfunction. Anesthesiology. 2009; 110 (3): 548-555. http://dx.doi.org/10 1097/ALN.0b013e318195b569. PMID: 19225398

7. Steiner L. Postoperative delirium. part 2: detection, prevention and treatment. Eur. J. Anaestesiol. 2011; 28 (10): 723-732. http://dx.doi. org/10. 1097/EJA.0b013e328349b7db. PMID: 21912241

8. Лихваниев В.В., Куликов В.А., Большедворов Р.В., Кичин В.В., Федоров C.A. Возможные причины и пути профилактики коротких послеоперационных психических нарушений при регионарной и общей анестезии. Анестезиология и реаниматология. 2008; 6: 71-74. PMID: 19230182

9. Young J., Murthy L., Westby M., Akunne A., O'Mahony R.; Guideline Development Group. Diagnosis, prevention, and management of delirium: summary of NICE guidance. BMJ. 2010; 341: 3704. http://dx.doi. org/10. 1136/bmj.c3704. PMID: 20667955

10. Лихванцев В.В. (ред.). Ингаляционная индукция и поддержание анестезии. М.: МИА; 2013: 320.

11. Лихванцев В.В., Гребенчиков О.А., Шмелева К., Борисов К.Ю., Шайбакова В.Л., Левиков Д.И. Анестезия у больных с сопутствующими цереброваскулярными заболеваниями: нейропротекция и нейротоксичность ингаляционных анестетиков. Вестн. интенс. терапии. 2012; 4: $28-34$

12. Inouye S.K., Charpentier P.A. Precipitating factors for delirium in hospitalized elderly persons. Predictive model and interrelationship with baseline vulnerability. JAMA. 1996; 275 (11): 852-857. http://dx.doi. org/10.1001/jama.1996.03530350034031. PMID: 8596223

13. Международная статистическая классификация болезней и проблем, связанных со здоровьем. Десятый пересмотр (МКБ-10). Женева: ВО3; 1995: 317.

14. Diagnostic and statistical manual of mental disorders (Fourth edition text revision (DSM-IV-TR). Washington, DC: American Psychiatric Association; 2000: 955.

15. Diagnostic and statistical manual of mental disorders. Arlington, VA: American Psychiatric Publishing; 2013: 1000.

16. Яхно Н.Н., Захаров В.В. Легкие когнитивные расстройства в пожилом возрасте. Неврологический журнал. 2004; 9 (1): 4-8.

17. Murkin J., Nerwman S., Stump D., Blumenthal J. Statement of consensus on assessment of neurobehavioral outcomes after cardiac surgery. Ann. Thorac. Surg. 1995; 59 (5): 1289-1295. http://dx.doi.org/10.1016/ 0003-4975(95)00106-U. PMID: 7733754

18. Blumenthal J., Mahanna E., Madden D., White W., Croughwell N., Nerman M. Methodological issues in the assessment of neuropsychologic function after cardiac surgery. Ann. Thorac. Surg. 1995; 59 (5): 1345-1350. http://dx.doi.org/10.1016/0003-4975(95)00055-P. PMID: 7733766

19. Hanning C.D. Postoperative cognitive dysfunction. Br. J. Anaesth. 2005; 95 (1): 82-87. http://dx.doi.org/10.1093/bja/aei062. PMID: 15640305

20. Makensen G., Gelb A. Postoperative cognitive deficits: more questions than answers. Eur. J. Anaesthesiol. 2004; 21 (2): 85-88. http://dx.doi.org/10.1017/S0265021504002017. PMID: 14977337

21. Wu C., Hsu W., Richman J., Raja S. Postoperative cognitive function as an outcome of regional anesthesia and analgesia. Reg. Anesth. Pain Med. 2004; 29 (3): 257-268. http://dx.doi.org/10.1097/00115550200405000-00013. PMID: 15138912

22. Moller J., Cluitmans P., Rasmussen L., Houx P., Rasmussen H., Canet J., Rabbitt P., Jolles J., Larsen K., Hanning C., Langeron O., Johnson T., Lauven P., Kristensen P., Biedler A., van Beem H., Fraidakis O., Silverstein J., Beneken J., Gravenstein J. Long-term postoperative cognitive dysfunction in the elderly ISPOCD1 study. ISPOCD investigators. International Study of Post-Operative Cognitive Dysfunction. Lancet. 1998; $351 \quad$ (9106): 857-861. http://dx.doi.org/ 10.1016/S0140-6736(97)07382-0. PMID: 9525362

23. Bigler D., Adelhoj B., Petring O.U., Pederson N.O., Busch P., Kalhke P. Mental function and morbidity after acute hip surgery during spinal and general anaesthesia. Anaesthesia. 1985; 40 (7): 672-676. http://dx.doi.org/10.1111/j.1365-2044.1985.tb10949.x. PMID: 4025772
3. Rasmussen L.S., Larsen K., Houx P., Skovgaard L.T., Hanning C.D., Moller J.T.; ISPOCD group. The assessment of postoperative cognitive function. Acta Anaesthesiol. Scand 2001; 45 (3): 275-289. http://dx.doi.org/10.1034/j.1399-6576.2001.045003275.x. PMID: 11207462

4. Price C.C., Garvan C.W., Monk T.G. Type and severity of cognitive decline in older adults after noncardiac surgery. Anesthesiology. 2008; 108 (1): 8-17. http://dx.doi.org/10.1097/01.anes.0000296072. 02527.18. PMID: 18156877

5. Robinson T.N., Raeburn C.D., Tran Z.V., Angles E.M., Brenner L.A., Moss $M$. Postoperative delirium in the elderly: risk factors and outcomes. Ann. Surg. 2009; 249 (1): 173-178. http://dx.doi.org/10.1097/SLA. 0b013e31818e4776. PMID: 19106695

6. SteinmetzJ., Christensen K.B., Lund T., Lohse N., Rasmussen L.S.; ISPOCD Group. Long-term consequences of postoperative cognitive dysfunction. Anesthesiology. 2009; 110 (3): 548-555. http://dx.doi.org/10. 1097/ALN.0b013e318195b569. PMID: 19225398

7. Steiner L. Postoperative delirium. part 2: detection, prevention and treatment. Eur. J. Anaestesiol. 2011; 28 (10): 723-732. http://dx.doi. org/10. 1097/EJA.0b013e328349b7db. PMID: 21912241

8. Likhvantsev V.V., Kulikov V.A., Bolshedvorov R.V., Kichin V.V., Fedorov $S . A$. Vozmozhnye prichiny i puti profilaktiki korotkikh posleoperatsionnykh psikhicheskikh narushenii pri regionarnoi i obshchei anestezii. [Possible causes and prevention ways of short-term postoperative mental disorders after regional and general anesthesia]. Anesteziologiya i Reanimatologiya. 2008; 6: 71-74. PMID: 19230182. [In Russ.]

9. Young J., Murthy L., Westby M., Akunne A., O'Mahony R.; Guideline Development Group. Diagnosis, prevention, and management of delirium: summary of NICE guidance. BMJ. 2010; 341: 3704. http://dx.doi. org/10. 1136/bmj.c3704. PMID: 20667955

10. Likhvantsev V.V. (red.). Ingalyatsionnaya induktsiya i podderzhanie anestezii. [Inhaled induction and maintenance of anesthesia]. Moscow: Meditsinskoe Informatsionnoe Agentstvo; 2013: 320. [In Russ.]

11. Likhvantsev V.V., Grebenchikov O.A., Shmeleva K., Borisov K.Yu. Shaibakova V.L., Levikov D.I. Anesteziya u bolnykh s soputstvuyushchimi tserebrovaskulyarnymi zabolevaniyami: neiroprotektsiya i neirotoksichnost ingalyatsionnykh anestetikov. [Anesthesia in patients with concomitant cerebrovascular diseases: neuroprotection and neurotoxicity of inhaled anesthetics]. Vestnik Intensionoi Terapii. 2012; 4: 28-34. [In Russ.]

12. Inouye S.K., Charpentier P.A. Precipitating factors for delirium in hospitalized elderly persons. Predictive model and interrelationship with baseline vulnerability. JAMA. 1996; 275 (11): 852-857. http://dx.doi. org/10.1001/jama.1996.03530350034031. PMID: 8596223

13. Mezhdunarodnaya statisticheskaya klassifikatsiya boleznei, svyazannykh so zdorovyem. Desyatyi peresmotr (MKB-10). [International statistical classification of diseases and related health problems. Tenth Revision (ICD-10)]. Zeneva: VOZ; 1995: 317. [In Russ.]

14. Diagnostic and statistical manual of mental disorders (Fourth edition text revision (DSM-IV-TR). Washington, DC: American Psychiatric Association; 2000: 955.

15. Diagnostic and statistical manual of mental disorders. Arlington, VA: American Psychiatric Publishing; 2013: 1000.

16. Yakhno N.N., Zakharov V.V. Legkie kognitivnye rasstroistva v pozhilom vozraste. [Mild cognitive impairments in the elderly]. Nevrologichesky Zhurnal. 2004; 9 (1): 4-8. [In Russ.]

17. Murkin J., Newman S., Stump D., BlumenthalJ. Statement of consensus on assessment of neurobehavioral outcomes after cardiac surgery. Ann. Thorac. Surg. 1995; 59 (5): 1289-1295. http://dx.doi.org/10.1016 0003-4975(95)00106-U. PMID: 7733754

18. Blumenthal J., Mahanna E., Madden D., White W., Croughroell N., Newman $M$. Methodological issues in the assessment of neuropsychologic function after cardiac surgery. Ann. Thorac. Surg. 1995; 59 (5): 1345-1350. http://dx.doi.org/10.1016/0003-4975(95)00055-P. PMID: 7733766

19. Hanning C.D. Postoperative cognitive dysfunction. Br. J. Anaesth. 2005; 95 (1): 82-87. http://dx.doi.org/10.1093/bja/aei062. PMID: 15640305

20. Makensen G., Gelb A. Postoperative cognitive deficits: more questions than answers. Eur. J. Anaesthesiol. 2004; 21 (2): 85-88. http://dx.doi.org/10.1017/S0265021504002017. PMID: 14977337

21. Wu C., Hsu W., Richman J., Raja S. Postoperative cognitive function as an outcome of regional anesthesia and analgesia. Reg. Anesth. Pain Med. 2004; 29 (3): 257-268. http://dx.doi.org/10.1097/00115550200405000-00013. PMID: 15138912

22. Moller J., Cluitmans P., Rasmussen L., Houx P., Rasmussen H., Canet J., Rabbitt P., Jolles J., Larsen K., Hanning C., Langeron O., Johnson T., Lauven P., Kristensen P., Biedler A., van Beem H., Fraidakis O., Silverstein J., Beneken J., Gravenstein J. Long-term postoperative cognitive dysfunction in the elderly ISPOCD1 study. ISPOCD investigators. International Study of Post-Operative Cognitive Dysfunction. 
24. Campbell D.N., Lim M., Muir M.K., O’Sullivan G., Falcon M., Fison P., Woods $R$. A prospective randomised study of local versus general anaesthesia for cataract surgery. Anaesthesia. 1993; 48 (5): 422-428. http://dx.doi.org/10.1111/j.1365-2044.1993.tb07019.x. PMID: 8317653

25. Ghoneim M.M., Hinrichs J.V., O'Hara M.W. Mehta M.P., Pathak D., Kumar V., Clark C.R. Comparison of psychologic and cognitive functions after general or regional anesthesia. Anesthesiology. 1988; 69 (4): 507-515. http://dx.doi.org/10.1097/00000542-198810000-00010. PMID: 3177911

26. Neroman S., Stygall J., Hirani S., Shaefi S., Maze M. Postoperative cognitive dysfunction after noncardiac surgery. Anesthesiology. 2007; 106 (3): 572-590. http://dx.doi.org/10.1097/00000542-20070300000023. PMID: 17325517

27. Riis J., Lomholt B., Haxholdt O., Kehlet H., Valentin N., Danielsen $U$., Dyrberg $V$. Immediate and long-term mental recovery from general versus epidural anesthesia in elderly patients. Acta Anaesthesiol. Scand. 1983; 27 (1): 44-49. http://dx.doi.org/10.1111/j.1399-6576.1983. tb01903.x. PMID: 6837235

28. Steinmetz J., Funder K.S., Dahl B.T., Rasmussen L.S. Depth of anaesthesia and post-operative cognitive dysfunction. Acta Anaesthesiol. Scand 2010; 54 (2): 162-168. http://dx.doi.org/10.1111/j.1399 6576.2009.02098.x. PMID: 19764909

29. Bergeron N., Dubois M. J., Dumont M., Dial S., Skrobik Y. Intensive Care Delirium Screening Checklist: evaluation of a new screening tool. Intensive Care Med. 2001; 27 (5): 859-864. http://dx.doi.org/ 10.1007/s001340100909. PMID: 11430542

30. Ely E.W., Inouye S.K., Bernard G.R., Gordon S., Francis J., May L., Truman B., Speroff T., Gautam S., Margolin R., Hart R.P., Dittus R. Delirium in mechanically ventilated patients: validity and reliability of the confusion assessment method for the intensive care unit (CAMICU).JAMA. 2001; 286 (21): 2703-2710. http://dx.doi.org/10.1001/ jama.286.21.2703. PMID: 11730446

31. Ely E.W., Stephens R.K.,Jackson J.C., Thomason J.W., Truman B., Gordon S., Dittus R.S., Bernard G.R. Current opinions regarding the importance, diagnosis, and management of delirium in the intensive care unit: a survey of 912 healthcare professionals. Crit. Care Med. 2004; 32 (1): 106-112. http://dx.doi.org/10.1097/01.CCM.0000098033. 94737.84. PMID: 14707567

32. Jacobi J., Fraser G.L., Coursin D.B., Riker R.R., Fontaine D., Wittbrodt E.T. Chalfin D.B., Masica M.F. Bjerke H.S., Coplin W.M. Crippen D.W., Fuchs B.D., Kelleher R.M., Marik P.E., Nasraway S.A.Jr., Murray M.J., Peruzzi W.T., Lumb P.D.; Task Force of the American College of Critical Care Medicine (ACCM) of the Society of Critical Care Medicine (SCCM), American Society of Health-System Pharmacists (ASHP), American College of Chest Physicians. Clinical practice guidelines for the sustained use of sedatives and analgesics in the critically ill adult. Crit. Care Med. 2002; 30 (1): 119-141. http://dx.doi.org/ 10.1097/00003246-200201000-00020. PMID: 11902253

33. Ouimet S., Riker R., Bergeron N., Cossette M., Kavanagh B., Skrobik Y. Subsyndromal delirium in the ICU: evidence for a disease spectrum. Intensive Care Med. 2007; 33 (6): 1007-1013. http://dx.doi.org/ 10.1007/s00134-007-0618-y. PMID: 17404704

34. Freitas S., Simões M.R., Alves L., Santana I. Montreal cognitive assessment: validation study for mild cognitive impairment and Alzheimer disease. Alzheimer Dis. Assoc. Disord. 2013; 27 (1): 37-43. http://dx.doi.org/10.1097/WAD.0b013e3182420bfe. PMID: 22193353

35. Hachinski V., Iadecola C., Petersen R.C., Breteler M.M., Nyenhuis D.L Black S.E., Powers W.J., De Carli C., Merino J.G., Kalaria R.N., Vinters H.V., Holtzman D.M., Rosenberg G.A., Wallin A., Dichgans M., Marler J.R., Leblanc G.G. National Institute of Neurological Disorders and Stroke-Canadian Stroke Network vascular cognitive impairment harmonization standards. Stroke. 2006; 37 (9): 2220-2241. http://dx. doi.org/10.1161/01.STR.0000237236.88823.47. PMID: 16917086

36. Chertkow H., Massoud F., Nasreddine Z., Belleville S., Joanette Y., Bocti $C$. Drolet V., Kirk J. Freedman M., Bergman H. Diagnosis and treatment of dementia: 3. Mild cognitive impairment and cognitive impairment without dementia. CMAJ. 2008; 178 (10): 1273-1285. http://dx. doi.org/10.1503/cmaj.070797. PMID: 18458258

37. Nagaraja D., Jayaashree $S$. Randomized study of the dopamine receptor agonist piribedil in the treatment of mild cognitive impairment Am. J. Psychiatry. 2001; 158 (9): 1517-1519. http://dx.doi.org/10 1176/appi.ajp.158.9.1517. PMID: 11532743

38. Nasreddine Z.S., Phillips N.A., Bédirian V., Charbonneau S., Whitehead V., Collin I., Cummings J.L., Chertkow H. The Montreal Cognitive Assessment, MoCA: a brief screening tool for mild cognitive impairment. J. Am. Geriatr. Soc. 2005; 53 (4): 695-699. http://dx.doi.org/ 10.1111/j.1532-5415.2005.53221.x. PMID: 15817019

39. Белобородова Н.В., Дмитриева И.Б., Чериевская Е.А. Диагностическая значимость белка S100B при критических состояниях. Общая реаниматология. 2011; 7 (6): 72-76. http://dx.doi.org/10.15360/ 1813-9779-2011-6-72
Lancet. 1998; 351 (9106): 857-861. http://dx.doi.org/10.1016/ S0140-6736(97)07382-0. PMID: 9525362

23. Bigler D., Adelhoj B., Petring O.U., Pederson N.O., Busch P., Kalhke P. Mental function and morbidity after acute hip surgery during spinal and general anaesthesia. Anaesthesia. 1985; 40 (7): 672-676. http://dx.doi.org/10.1111/j.1365-2044.1985.tb10949.x. PMID: 4025772

24. Campbell D.N., Lim M., Muir M.K., O'Sullivan G., Falcon M., Fison $P$., Woods $R$. A prospective randomised study of local versus general anaesthesia for cataract surgery. Anaesthesia. 1993; 48 (5): 422-428. http://dx.doi.org/10.1111/j.1365-2044.1993.tb07019.x. PMID: 8317653

25. Ghoneim M.M., Hinrichs J.V., O'Hara M.W., Mehta M.P., Pathak D., Kumar V., Clark C.R. Comparison of psychologic and cognitive functions after general or regional anesthesia. Anesthesiology. 1988; 69 (4): 507-515. http://dx.doi.org/10.1097/00000542-198810000-00010. PMID: 3177911

26. Newman S., Stygall J., Hirani S., Shaefi S., Maze M. Postoperative cognitive dysfunction after noncardiac surgery. Anesthesiology. 2007; 106 (3): 572-590. http://dx.doi.org/10.1097/00000542-20070300000023. PMID: 17325517

27. Riis J., Lomholt B., Haxholdt O., Kehlet H., Valentin N., Danielsen $U$., Dyrberg $V$. Immediate and long-term mental recovery from genera versus epidural anesthesia in elderly patients. Acta Anaesthesiol. Scand. 1983; 27 (1): 44-49. http://dx.doi.org/10.1111/j.1399-6576.1983. tb01903.x. PMID: 6837235

28. Steinmetz J., Funder K.S., Dahl B.T., Rasmussen L.S. Depth of anaesthesia and post-operative cognitive dysfunction. Acta Anaesthesiol. Scand. 2010; 54 (2): 162-168. http://dx.doi.org/10.1111/j.1399-6576 2009.02098.x. PMID: 19764909

29. Bergeron N., Dubois M.J., Dumont M., Dial S., Skrobik Y. Intensive Care Delirium Screening Checklist: evaluation of a new screening tool Intensive Care Med. 2001; 27 (5): 859-864. http://dx.doi.org/ 10.1007/s001340100909. PMID: 11430542

30. Ely E.W., Inouye S.K., Bernard G.R., Gordon S., Francis J., May L., Truman B., Speroff T., Gautam S., Margolin R., Hart R.P., Dittus R Delirium in mechanically ventilated patients: validity and reliability of the confusion assessment method for the intensive care unit (CAMICU).JAMA. 2001; 286 (21): 2703-2710. http://dx.doi.org/10.1001/ jama.286.21.2703. PMID: 11730446

31. Ely E.W., Stephens R.K.,Jackson J.C., Thomason J.W., Truman B., Gordon S., Dittus R.S., Bernard G.R. Current opinions regarding the importance, diagnosis, and management of delirium in the intensive care unit: a survey of 912 healthcare professionals. Crit. Care Med. 2004; 32 (1): 106-112. http://dx.doi.org/10.1097/01.CCM.0000098033. 94737.84. PMID: 14707567

32. Jacobi J., Fraser G.L., Coursin D.B., Riker R.R., Fontaine D., Wittbrodt E.T., Chalfin D.B., Masica M.F., Bjerke H.S., Coplin W.M., Crippen D.W., Fuchs B.D., Kelleher R.M., Marik P.E., Nasraway S.A.Jr., Murray M.J., Peruzzi W.T., Lumb P.D.; Task Force of the American College of Critical Care Medicine (ACCM) of the Society of Critical Care Medicine (SCCM), American Society of Health-System Pharmacists (ASHP), American College of Chest Physicians. Clinical practice guidelines for the sustained use of sedatives and analgesics in the critically ill adult. Crit. Care Med. 2002; 30 (1): 119-141. http://dx.doi.org/ 10.1097/00003246-200201000-00020. PMID: 11902253

33. Ouimet S., Riker R., Bergeron N., Cossette M., Kavanagh B., Skrobik Y. Subsyndromal delirium in the ICU: evidence for a disease spectrum. Intensive Care Med. 2007; 33 (6): 1007-1013. http://dx.doi.org/ 10.1007/s00134-007-0618-y. PMID: 17404704

34. Freitas S., Simões M.R., Alves L., Santana I. Montreal cognitive assessment: validation study for mild cognitive impairment and Alzheimer disease. Alzheimer Dis. Assoc. Disord. 2013; 27 (1): 37-43. http://dx. doi.org/10.1097/WAD.0b013e3182420bfe. PMID: 22193353

35. Hachinski V., Iadecola C., Petersen R.C., Breteler M.M., Nyenhuis D.L., Black S.E., Powers W.J., De Carli C., Merino J.G., Kalaria R.N., Vinters H.V. Holtzman D.M., Rosenberg G. A. Wallin A, Dichsans M., Marler J.R., Leblanc G.G. National Institute of Neurological Disorders and Stroke-Canadian Stroke Network vascular cognitive impairment harmonization standards. Stroke. 2006; 37 (9): 2220-2241. http://dx doi.org/10.1161/01.STR.0000237236.88823.47. PMID: 16917086

36. Chertkow H., Massoud F., Nasreddine Z., Belleville S., Joanette Y., Boct C., Drolet V., KirkJ., Freedman M., Bergman H. Diagnosis and treatment of dementia: 3. Mild cognitive impairment and cognitive impairment without dementia. CMAJ. 2008; $178 \quad$ (10): 1273-1285. http://dx.doi.org/10.1503/cmaj.070797. PMID: 18458258

37. Nagaraja D., Jayaashree $S$. Randomized study of the dopamine receptor agonist piribedil in the treatment of mild cognitive impairment Am. J. Psychiatry. 2001; 158 (9): 1517-1519. http://dx.doi.org/10. 1176/appi.ajp.158.9.1517. PMID: 11532743

38. Nasreddine Z.S., Phillips N.A., Bédirian V., Charbonneau S., Whitehead V., Collin I., Cummings J.L., Chertkow H. The Montreal Cognitive Assessment, MoCA: a brief screening tool for mild cognitive impairment. J. Am. Geriatr. Soc. 2005; 53 (4): 695-699. http://dx.doi.org/ 10.1111/j.1532-5415.2005.53221.x. PMID: 15817019 
40. Ely E.W., Margolin R., Francis J., May L., Truman B., Dittus R., Speroff T., Gautam S., Bernard G.R., Inouye S.K. Evaluation of delirium in critically ill patients: validation of the Confusion Assessment Method for the Intensive Care Unit (CAM-ICU) Crit. Care Med. 2001; 29 (7): 1370-1379. http://dx.doi.org/10.1097/00003246-200107000-00012. PMID: 11445689

41. ICU Delirium and Cognitive Impairment Study Group. http:// www.icudelirium.org/delirium/monitoring.htm.

42. www.mocatest.org

43. Глушко А.Н. Основы психометрии. М.: изд-во Министерства обороны РФ; 1994: 91.

44. Rasmussen L., Stygall J., Newman S. Cognitive dysfunction and other long-term complications of surgery and anesthesia. In: Miller D. (ed.). Miller's Anesthesia. 2009; 2 (7): 2805-2820. http://dx.doi.org/10. 1016/B978-0-443-06959-8.00089-3

45. Keith J.R., Puente A.E., Malcolmson K.L., Tartt S., Coleman A.E., Marks H.F.Jr. Assessing postoperative cognitive change after cardiopulmonary bypass surgery. Neuropsychology. 2002; $16 \quad$ (3): 411-421. http://dx.doi.org/10.1037//0894-4105.16.3.411. PMID: 12146688

46. Гусев Е.И., Сквориова В.И. Ишемия головного мозга. М.: Медицина; 2001: 328 .

47. Browne S.M, Halligan PW, Wade DT, Tagoart D P Postoperative hypoxia is a contributory factor to cognitive impairment after cardiac surgery. J. Thorac. Cardiovasc. Surg. 2003; 126 (4): 1061-1064. http://dx.doi.org/10.1016/S0022-5223(03)00616-0. PMID: 14566247

48. Burkhart C.S., Steiner L.A. Can postoperative cognitive dysfunction be avoided? Hosp. Pract. (1995). 2012; 40 (1): 214-223. http://dx.doi.org/10.3810/hp.2012.02.962. PMID: 22406897

49. Ancelin M.L., de Roquefeuil G., Ledesert B., Bonnel F., Cheminal J.C., Ritchie $K$. Exposure to anaesthetic agents, cognitive functioning and depressive symptomatology in the elderly. Br.J. Psychiatry. 2001; 178: 360-366. http://dx.doi.org/10.1192/bjp.178.4.360. PMID: 11282816

50. Johnson T., Monk T., Rasmussen L.S., Abildstrom H., Houx P., Korttila K., Kuipers H.M., Hanning C.D., Siersma V.D., Kristensen D., Canet J., Ibanaz M.T., Moller J.T., ISPOCD2 Investigators. .Postoperative cognitive dysfunction in middle-aged patients. Anesthesiology. 2002; 96 (6): 1351-1357. http://dx.doi.org/10.1097/00000542-200206000-00014. PMID: 12170047

51. Leung J., Sands L., Mullen E., Wang Y., Vaurio L. Are preoperative depressive symptoms associated with postoperative delirium in geriatric surgical patients? J. Gerontol. A Biol. Sci. Med. Sci. 2005; 60 (12): 1563-1568. http://dx.doi.org/10.1093/gerona/60.12.1563. PMID: 16424289

52. Monk T.G., Weldon B.C., Garvan C.W., Dede D.E., van der Aa M.T., Heilman K.M., Gravenstein J.S. Predictors of cognitive dysfunction after major noncardiac surgery. Anesthesiology. 2008; 108 (1): 18-30. http://dx.doi.org/10.1097/01.anes.0000296071.19434.1e. PMID: 18156878

53. Stockton P., Cohen-Mansfield J., Billig N. Mental status change in older surgical patients. Cognition, depression, and other comorbidity. Am.J. Geriatr. Psychiatry. 2000; 8 (1): 40-46. http://dx.doi.org/10.1097/ 00019442-200002000-00006. PMID: 10648294

54. Мороз В.В., Корниенко А.Н., Мозалев А.С., Парфенюк А.В., Нахмаева C.B. Проблема повреждения головного мозга при кардиохирургических вмешательствах в условиях искусственного кровообращения. Общая реаниматология. 2008; 4 (4): 16-20. http://dx.doi.org/ 10.15360/1813-9779-2008-4-16

55. Шепелюк А.Н., Клыпа Т.В., Никифоров Ю.В. Факторы риска послеоперационных энцефалопатий в кардиохирургии. Общая реаниматология. 2012; 8 (5): 47-55. http://dx.doi.org/10.15360/1813-9779тология. $2012-5-47$

56. Шепелюк А.Н., Кльпа Т.В., Никифоров Ю.В. Церебральная оксиметрия для прогнозирования неврологической дисфункции у кардиохирургических пациентов. Общая реаниматология. 2011; 7 (1): 48-57. http://dx.doi.org/10.15360/1813-9779-2011-1-48

57. Заболотских И.Б., Рудометкин С.Г., Трембач Н.В. Предоперационные факторы риска развития делирия у пожилых пациентов после обширных абдоминальных операций. Вестн. анестезиологии и реаниматологии. 2012; 9 (4): 3-7.

58. Young., Inouye S. Delirium in older people. BMJ. 2007; 334 (7598): 842-846. http://dx.doi.org/10.1136/bmj.39169.706574.AD. PMID: 17446616

Поступила 10.06.14
39. Beloborodova N.V., Dmitriyeva I.B., Chernevskaya E.A. Diagnosticheskaya znachimost belka S100B pri kriticheskikh sostoyaniyakh. Obshchaya Reanimatologiya. [Diagnostic value of S100B protein in critical conditions. General Reanimatology]. 2011; 7 (6): 72-76. http://dx.doi.org/10.15360/1813-9779-2011-6-72. [In Russ.]

40. Ely E.W., Margolin R., Francis J., May L., Truman B., Dittus R., Speroff T., Gautam S., Bernard G.R., Inouye S.K. Evaluation of delirium in critically ill patients: validation of the Confusion Assessment Method for the Intensive Care Unit (CAM-ICU) Crit. Care Med. 2001; 29 (7): 1370-1379. http://dx.doi.org/10.1097/00003246-200107000-00012. PMID: 11445689

41. ICU Delirium and Cognitive Impairment Study Group. http:// www.icudelirium.org/delirium/monitoring.htm.

42. www.mocatest.org

43. Glushko A.N. Osnovy psikhometrii. [Fundamentals of psychometry]. Moscow: izd-vo Ministerstva Oborony RF; 1994: 91. [In Russ.]

44. Rasmussen L., Stygall J., Newman S. Cognitive dysfunction and other long-term complications of surgery and anesthesia. In: Miller D. (ed.). Miller's Anesthesia. 2009; 2 (7): 2805-2820. http://dx.doi.org/10. 1016/B978-0-443-06959-8.00089-3

45. Keith J.R., Puente A.E., Malcolmson K.L., Tartt S., Coleman A.E., Marks H.F.Jr. Assessing postoperative cognitive change after cardiopulmonary bypass surgery. Neuropsychology. 2002; 16 (3): 411-421. http://dx.doi.org/10.1037//0894-4105.16.3.411. PMID: 12146688

46. Gusev E.I., Skvortsova V.I. Ishemiya golovnogo mozga. [Brain ischemia]. Moscow: Meditsina Publishers; 2001: 328. [In Russ.]

47. Browne S.M., Halligan P.W., Wade D.T., Taggart D.P. Postoperative hypoxia is a contributory factor to cognitive impairment after cardiac surgery. J. Thorac. Cardiovasc. Surg. 2003; 126 (4): 1061-1064. http://dx.doi.org/10.1016/S0022-5223(03)00616-0. PMID: 14566247

48. Burkhart C.S., Steiner L.A. Can postoperative cognitive dysfunction be avoided? Hosp. Pract. (1995). 2012; 40 (1): 214-223. http://dx.doi.org/10.3810/hp.2012.02.962. PMID: 22406897

49. Ancelin M.L., de Roquefeuil G., Ledesert B., Bonnel F., Cheminal J.C., Ritchie $K$. Exposure to anaesthetic agents, cognitive functioning and depressive symptomatology in the elderly. Br. J. Psychiatry. 2001; 178: 360-366. http://dx.doi.org/10.1192/bjp.178.4.360. PMID: 11282816

50. Johnson T., Monk T., Rasmussen L.S., Abildstrom H., Houx P., Korttila K., Kuipers H.M., Hanning C.D., Siersma V.D., Kristensen D., Canet J., Ibanaz M.T., Moller J.T., ISPOCD2 Investigators. .Postoperative cognitive dysfunction in middle-aged patients. Anesthesiology. 2002; 96 (6): 1351-1357. http://dx.doi.org/10.1097/00000542-200206000-00014. PMID: 12170047

51. LeungJ., Sands L., Mullen E., Wang Y., Vaurio L. Are preoperative depressive symptoms associated with postoperative delirium in geriatric surgical patients? J. Gerontol. A Biol. Sci. Med. Sci. 2005; 60 (12): 1563-1568. http://dx.doi.org/10.1093/gerona/60.12.1563. PMID: 16424289

52. Monk T.G., Weldon B.C., Garvan C.W., Dede D.E., van der Aa M.T., Heilman K.M., Gravenstein J.S. Predictors of cognitive dysfunction after major noncardiac surgery. Anesthesiology. 2008; 108 (1): 18-30. http://dx.doi.org/ 10.1097/01.anes.0000296071.19434.1e. PMID: 18156878

53. Stockton P., Cohen-Mansfield J., Billig N. Mental status change in older surgical patients. Cognition, depression, and other comorbidity. Am.J. Geriatr. Psychiatry. 2000; 8 (1): 40-46. http://dx.doi.org/10.1097/ 00019442-200002000-00006. PMID: 10648294

54. Moroz V.V., Korniyenko A.N., Mozalev A.S., Parfenyuk A.V., Shakhmayeva S.V. Problema povrezhdeniya golovnogo mozga pri kardiokhirurgicheskikh vmeshatelstvakh v usloviyakh iskusstvennogo krovoobrashcheniya. Obshchaya Reanimatologiya. [Problem of brain injury during cardiosurgical interventions under extracorporeal circulation. General Reanimatology]. 2008; 4 (4): 16-20. http://dx.doi.org/ 10.15360/1813-9779-2008-4-16

55. Shepelyuk A.N., Klypa T.V., Nikiforov Yu.V. Faktory riska posleoperatsionnykh entsefalopatii v kardiokhirurgii. Obshchaya Reanimatologiya. [Risk factors for postoperative encephalopathies in cardiac surgery. General Reanimatology]. 2012; 8 (5): 47-55. http://dx.doi.org/ 10.15360/1813-9779-2012-5-47

56. Shepelyuk A.N., Klypa T.V., Nikiforov Yu.V. Tserebralnaya oksimetriya dlya prognozirovaniya nevrologicheskoi disfunktsii u kardiokhirurgicheskikh patsientov. Obshchaya Reanimatologiya. [Cerebral oximetry for the prediction of neurological dysfunction in cardiosurgical patients General Reanimatology]. 2011; 7 (1): 48-57. http://dx.doi.org/ 10.15360/1813-9779-2011-1-48

57. Zabolotskikh I.B., Rudometkin S.G., Trembach N.V. Predoperatsionnye faktory riska razvitiya deliriya u pozhilykh patsientov posle obshirnykh abdominalnykh operatsii. [Preoperative risk factors of delirium in elderly patients after extensive abdominal surgery]. Vestnik Anesteziologii i Reanimatologii. 2012; 9 (4): 3-7.

58. Young. J., Inouye S. Delirium in older people. BMJ. 2007; 334 (7598): 842-846. http://dx.doi.org/10.1136/bmj.39169.706574.AD. PMID 17446616

Submited 10.06.14 